\title{
30. ORGANIC GEOCHEMISTRY OF CENOZOIC AND MESOZOIC SEDIMENTS FROM DEEP SEA DRILLING SITES 544 TO 547, LEG 79, EASTERN NORTH ATLANTIC1
}

\author{
G. Deroo, J. P. Herbin, and J. Roucaché, Institut Français du Pétrole, Paris ${ }^{2}$
}

\begin{abstract}
Cenozoic and Mesozoic sediments ranging in age from Pleistocene to Early Jurassic/late Triassic were recovered on DSDP Leg 79, off Morocco at Sites 544 to 547 in front of the Mazagan Plateau. The main zone of oil genesis should be reached at Site 547 within the Jurassic section. Organic material of marine origin with good petroleum potential characterizes the late Eocene slumps of Site 547 and originates from reworked organic matter of Cretaceous origin. Organic enrichment also occurs at Site 545 during the middle to late Albian period. Since the organic matter appears to be autochthonous, reducing environments of deposition are inferred. In the other Cretaceous deposits, variably altered organic matter of the same origin predominates. Finally, a transect including Site 370 off the Agadir Canyon, is studied: detrital organic matter and reducing environments of deposition were more developed during Albian time for Site 370 than for Site 545.
\end{abstract}

\section{INTRODUCTION}

During Leg 79, a series of holes were drilled near the Mazagan Plateau to document the rifting and the subsidence of a passive margin bordering the early Atlantic (Fig. 1). Neogene foraminiferal and nannofossil oozes were drilled on all sites. From the northwest to the southeast, they respectively overlie a Jurassic salt sequence at Site 546, Jurassic limestones at Site 544, Paleogene siliceous nannochalk and claystone punctuated by debris flows at Site 547, and Cenomanian nannofossil claystone at Site 545. At Sites 545 and 547, Cretaceous nannofossil claystone deposits of Cenomanian to Aptian age were replete with slumps, pebbles, and microfaults which in turn overlie limestone, dolomite, and sandy mudstone of Jurassic age.

The present study characterizes geochemically the organic matter in the sedimentary rocks penetrated on DSDP Leg 79. Two sets of samples were obtained: (1) 271 samples of a few grams each were collected while on the cruise; (2) 29 larger samples were provided by the Organic Geochemistry Panel.

This paper consists of two parts, the first part composed of five sections. The first three sections of part one are devoted to mineral and organic carbon analyses and the pyrolysis of organic matter. The third section considers maturation, petroleum potential, and the nature of organic matter, respectively. In these sections, the description follows the drilling order, from top to bottom, through every lithological unit for each site. The fourth and fifth sections concern kerogen and chloroform extract studies on some selected samples. In part two, the vertical distribution of organic matter and the related environments of deposition are examined for the Early to mid-Cretaceous sections of Sites 545 and 547

\footnotetext{
${ }^{1}$ Hinz, K., Winterer, E. L., et al., Init. Repts, DSDP, 79: Washington (U.S. Govt. Printing Office).

2 Address: Institut Français du Pétrole, B.P. 311, 92503 Rueil Malmaison Cedex, France.
}

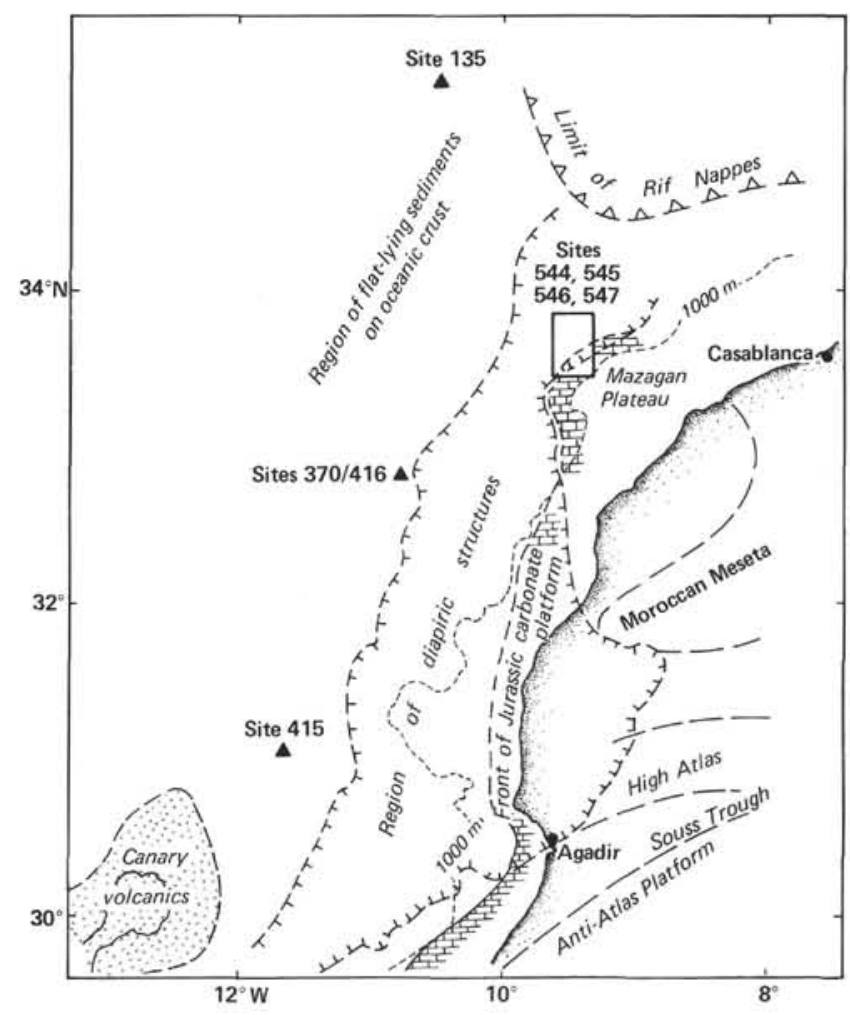

Figure 1. Location of DSDP Leg 79.

and are compared with a similar section at Site 370 . Tables 1-5 are contained in the Appendix to this chapter.

\section{METHODOLOGY}

Organic carbon was determined for 300 acid-treated samples with a LECO apparatus. A pyrolysis assay was conducted on equivalent samples by Rock-Eval (Espitalié et al., 1977). Seventeen samples were selected to be extracted with chloroform. Ten of these samples were analyzed by gas chromatography of saturate hydrocarbons. Kerogen concentrates were prepared (Huc et al., 1978) and elemental analysis performed on the same ten samples. 


\section{RESULTS}

\section{Mineral Carbon and Carbonates}

\section{Site 544}

A large carbonate fraction (58-80 wt.\% of $\mathrm{CaCo} 3$ equivalent) occurs in the clayey foraminiferal-nanno ooze of Unit I for Holes 544A and 544B (Fig. 2, Appendix Table 1). The carbonate content slightly increases from top to bottom, i.e., from Pleistocene to late Miocene in Hole 544B. In Hole 544A no samples were provided from Units II and III and the only sample obtained from Jurassic Unit IV was carbonate-poor $(15.3 \%)$ and belonged to the muddy sand lithofacies.

\section{Site 545}

The clayey foraminiferal-nanno ooze in Subunit IA of Pleistocene age reveals $30-60 \%$ carbonates against $60 \%$ or more in Subunit IB (Cores 10 to 20). Higher values in the latter are probably due to the presence of limestone pebbles and cobbles. The same carbonate content is found for the foram-nanno chalk of Unit II (Cores 20 to 27) except toward the bottom where the content decreases to $37 \%$ (Fig. 3, Appendix Table 2).

The carbonate content for the clayey facies of Subunit IIIA (Cores 28 to 44 ) is $30 \%$ and less but with many high values (up to 60\%) due to pebbles in Cores 34 to 44 . Along Subunit IIIB (Cores 45 to 55) where pervasive microfaults and folds are observed throughout, the carbonate distribution suggests a series of carbonate sequences with the values decreasing in each from $50-70 \%$ at the bottom to $40 \%$ at the top. A $50 \%$ content is found in Subunit IIIC (Sections 545-55-6 to 545-56-7). For all of Unit III, carbonate content increases down hole from $20 \%$ at the top to $60 \%$ at the bottom.

\section{Site 546}

Within the nanno ooze and the foraminiferal-nanno ooze of Unit I, Pleistocene to late Miocene in age, a range of values from 40 to $77 \%$ was observed (Fig. 4,
Appendix Table 3). The lithofacies of Unit II includes two different ranges: (1) $15-33 \%$ for the grayish red claystone and (2) 63-76\% for the greenish and reddish brown calcareous claystone. Low values of 13 and $14 \%$ correspond to the gypsiferous sandy claystone at the bottom of Unit II.

\section{Site 547}

As observed for Site 545, the Pleistocene part of the clayey nannofossil ooze in Unit I contains less than $60 \%$ of carbonates compared with $60-80 \%$ for both the Pliocene-Miocene part and the foram-nanno ooze of Subunit IIA (Fig. 5, Appendix Table 4). About $40 \%$ is found for the nannofossil clay of Subunit IIB. A $60-80 \%$ range recurs for the conglomeratic clayey Unit III and for the chalk facies of Subunit IVA. A 41-56\% content characterizes the clayey facies of the same subunit. However, 44-74\% of carbonates were found in Subunit IVB except on both ends where the contents fall between 21 and $31 \%$. Units I-IV have carbonate contents of $60 \%$ or more, which is high when compared to Unit V.

Unit V is $30 \%$ at the top but increases downward to $60 \%$ near the bottom and is composed of claystone and calcareous claystone with subordinate pebbly to cobbly claystone and mudstone. Unit V can be subdivided into three parts: (1) an upper part, from Cores $547 \mathrm{~A}-40$ to 517A-66 with carbonate contents ranging from 21 to $45 \%$, with the richer contents of $30 \%$ or more found in cores where pebbly layers occur; (2) a middle part, in Cores 547A-67 to 547A-72 with a higher range of values from 46 to $72 \%$; and (3) a lower part, from Core 547A73 to $547 \mathrm{~B}-5$ where the contents fall to $37 \%$ or less.

The limestone and claystone sequence of Unit VI was not sampled. Beneath it, the red and gray sandy mudstone of Unit VII includes carbonate contents that range from 14 to $36 \%$.

\section{Summary}

For Sites 544, 545, 546, and 547, a carbonate-poor facies characterizes the Pleistocene and a carbonate-rich
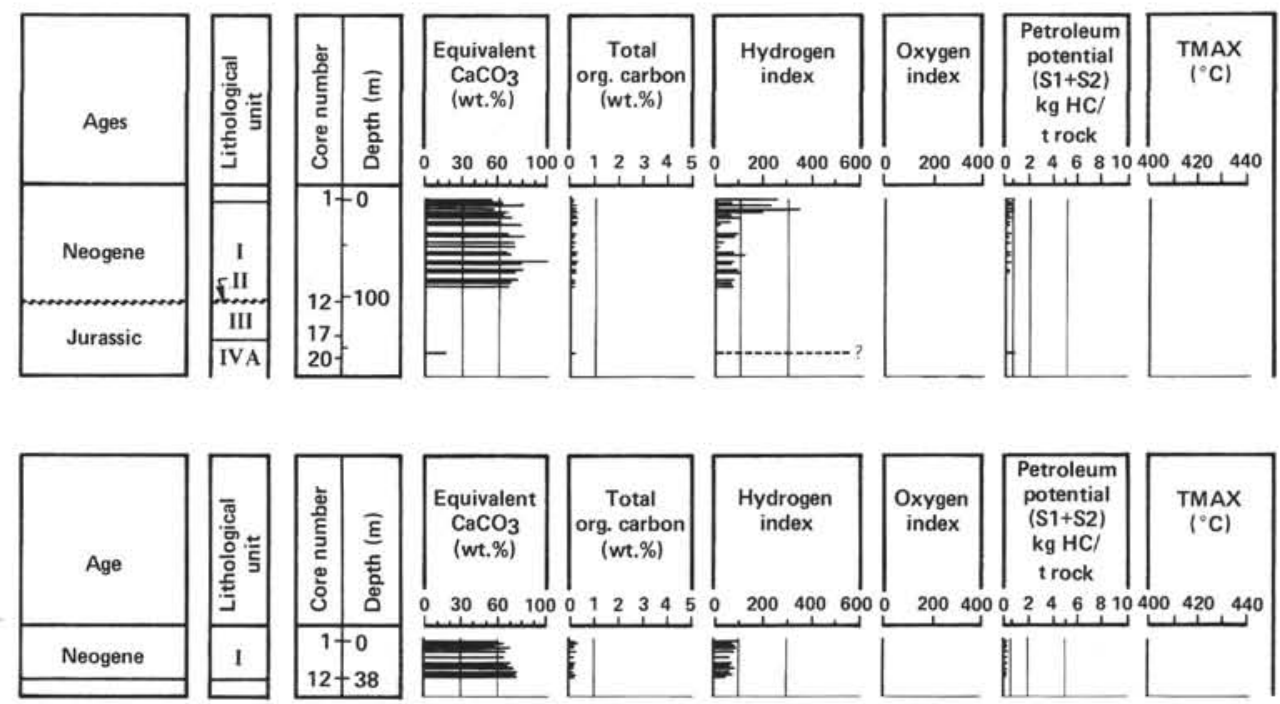

Figure 2. Vertical distribution of carbon and pyrolysis assay data, Holes 544A and 544B. 


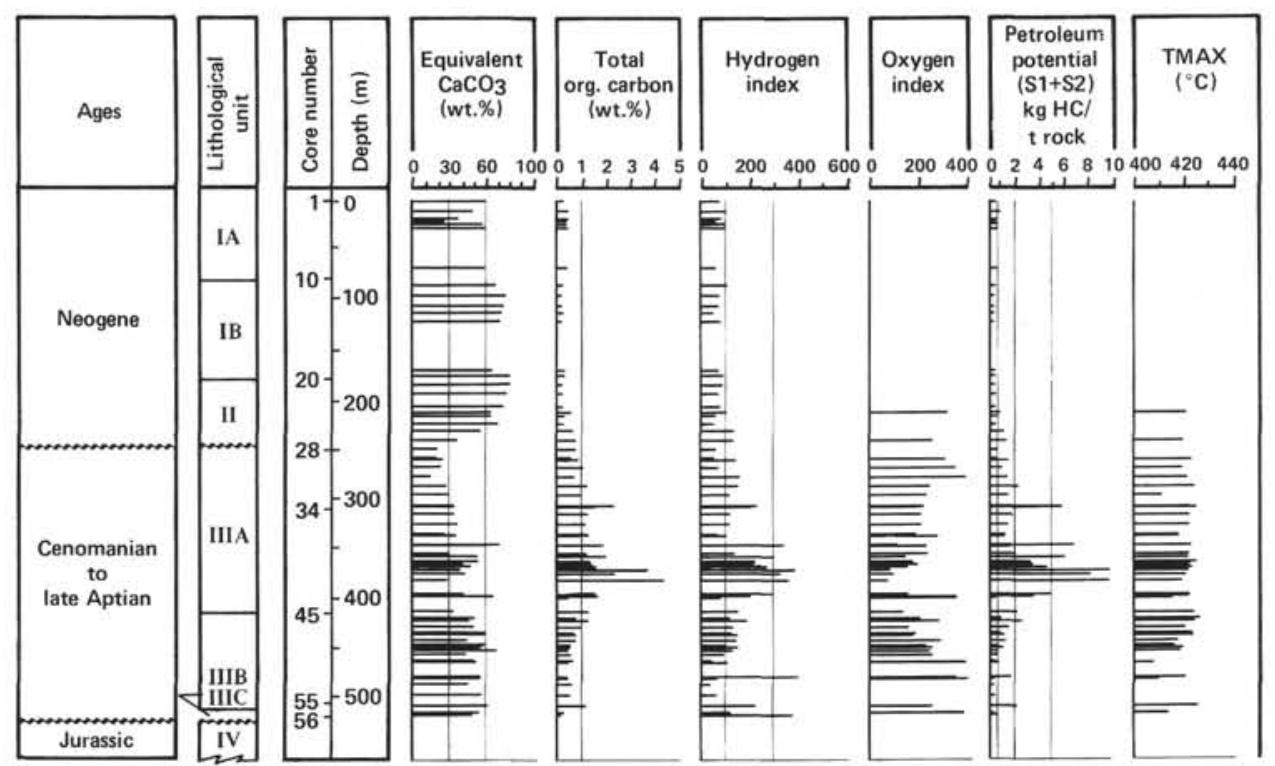

Figure 3. Vertical distribution of carbon and pyrolysis assay data, Hole 545.

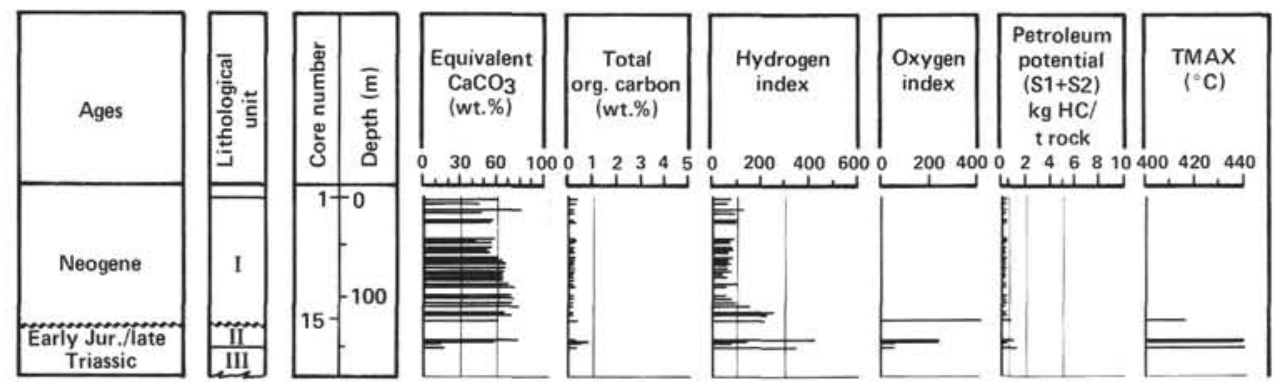

Figure 4. Vertical distribution of carbon and pyrolysis assay data, Hole 546.

(60\% or more) facies characterizes the Pliocene-Miocene section. In the underlying Cretaceous sections cored in Holes 545, 547A, and 547B, the carbonate-poor (15 to $44 \%$ ) facies corresponds to the Cenomanian rocks whereas some high (up to $60 \%$ ) carbonate values occur in the Albian section. Sequences with carbonate contents increasing down hole are observed for the late Aptian at Site 545 while low carbonate values were found for the Jurassic sampled at the bottom of Hole 547B.

\section{Organic Carbon}

The distribution of total organic carbon contents observed in the holes may be classified as follows: very rich, more than 3 wt. \%; rich, 1.01 to $3.00 \mathrm{wt} . \%$; average, 0.51 to $1.00 \mathrm{wt} . \%$; low, 0.21 to $0.50 \mathrm{wt} . \%$; and very low, $0.20 \mathrm{wt} . \%$ and less.

\section{Site 544}

Very low to low organic carbon contents occur for Unit I in both Hole 544A $(0.09-0.21 \%)$ and Hole 544B $(0.07-0.28 \%)$ and in Unit IV of Hole 544A $(0.13 \%)$ (Fig. 2, Appendix Table 1).

\section{Site 545}

Very low organic carbon content $(0.14-0.19 \%)$ characterizes Units I and II except for the slightly richer clayey facies of Subunit IA and at the bottom of Unit II $(0.28-0.77 \%$ ) (Fig. 3, Appendix Table 2). In Unit III, most samples of Subunit IIIA (Cores 28 to 45 ) reveal a content of $1.0 \%$ or more, and richer levels (1.94-4.46\%) characterize the lower part of the subunit. Low to average contents $(0.37-0.70 \%)$ are observed throughout Subunit IIIB (Sections 545-45-1 to 545-55-6) and the richest organic contents correspond to the lowest carbonate contents. Very low organic contents $(0.09-0.24 \%)$ are found along Subunit IIIC (Sections 545-55-6 to 545-56-7).

\section{Site 546}

As previously observed in Sites 544 and 545 , Unit I reveals very low contents of organic carbon $(0.07-0.23 \%)$ except at the top and at the bottom where low contents occur $(0.25-0.32 \%)$. Low contents $(0.27-0.41 \%)$ are also found for the gypsiferous levels of Unit II. (Fig. 4, Appendix Table 3)

\section{Site 547}

Very low to low organic carbon contents $(0.10-0.50 \%)$ characterize Units I and II (Fig. 5, Appendix Table 4). Rich and very rich levels $(2.28-3.11 \%)$ occur in Unit III. Within Unit IV, very low to low organic carbon contents $(0.10-0.44 \%)$ are observed with a slight increase at the top and bottom $(0.62-0.66 \%)$. Within Unit V, a pro- 


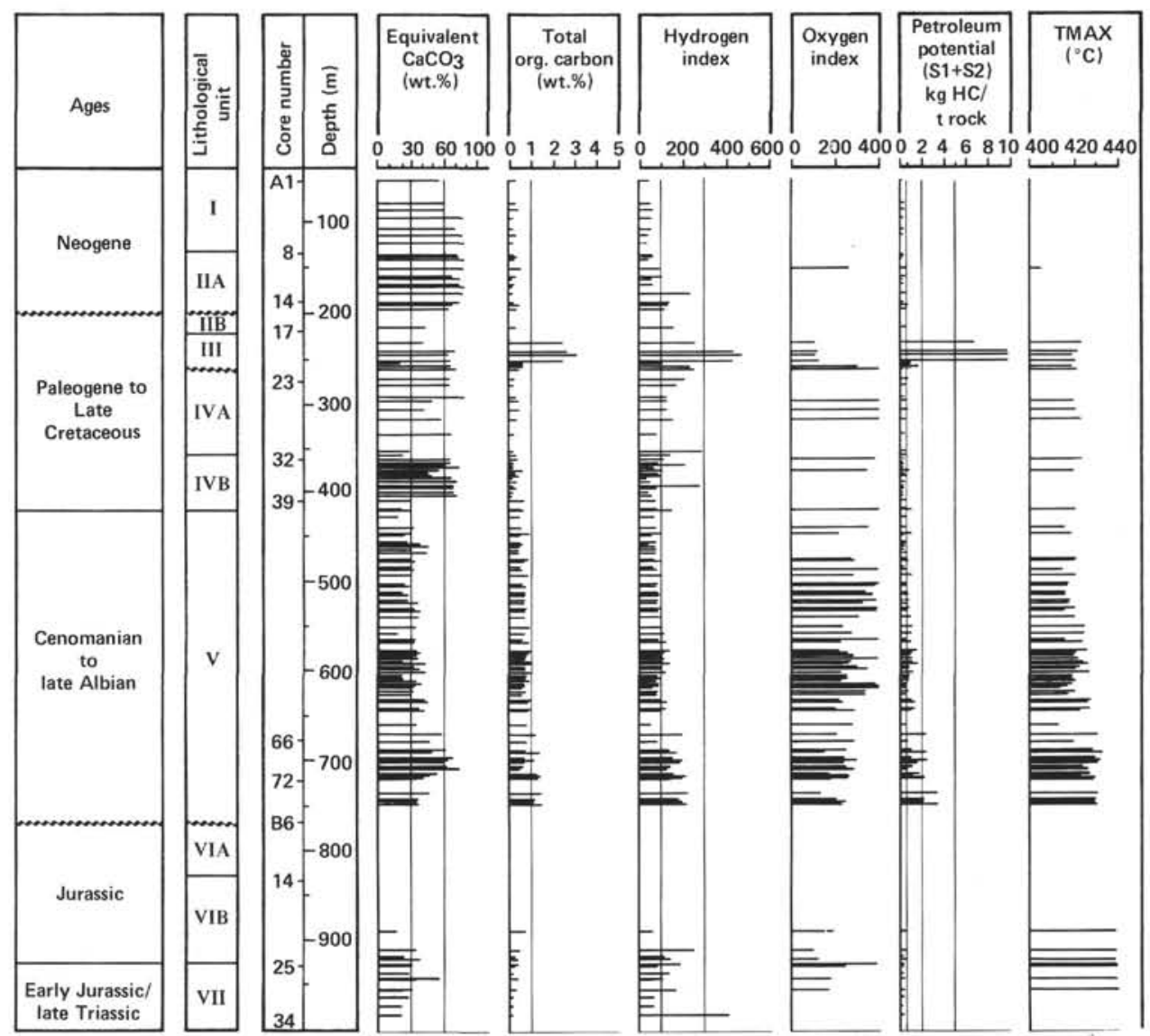

Figure 5. Vertical distribution of carbon and pyrolysis assay data, Holes 547A and 547B.

gressive enrichment is observed downward, from $0.50 \%$ in Core $547 \mathrm{~A}-41$ to $1.49 \%$ in Core $547 \mathrm{~B}-5$ at the bottom. In the latter part, many low values or impoverishments, presumably related to carbonate pebbly material, disturb that trend.

Given the average of the analyses performed on board, rich and very rich levels $(0.63-6.76 \%)$ characterize Unit VI. In Unit VII, the organic carbon content varies from $0.44 \%$ to $0.07 \%$ at the bottom.

\section{Summary}

For the several holes analyzed, a negative correlation between carbonate content and organic carbon content was observed along the Cenozoic series, except for the Eocene slumps of Unit III in Hole 547A where organic carbon poor and organic carbon rich samples are both found in carbonate-rich material. Such a correlation is again observed for the Albian and Aptian deposits of Hole 545 within Unit III (Cores 34 to 55) and for Holes 547A and 547B within Unit V (Cores 547A-58 to 547B-5).

\section{Pyrolysis of Organic Matter}

\section{Maturation}

\section{Method}

During the pyrolysis of organic matter by Rock-Eval, the temperatures reached at the maximum of hydrocarbon production (TMAX) for peak S2 depend both on the stage of maturation and the nature of the organic matter (Espitalié and Deroo, in press). The TMAX can be plotted against hydrogen indices (Fig. 6, 7) to estimate the maturation of samples. Evolution paths for the three reference types of organic matter (types I, II, and III) are outlined in the figures. When maturation increases, hydrogen indices decrease; however the pyrolysis temperatures (TMAX) also increase. The variation follows the trend of the evolution paths. Isoreflectance curves $(0.5,1.0,1.5)$ superimposed on the graph can be compared with the maturation scale compiled from other studies using vitrinite reflectance data (Espitalié et al., in press). Isoreflectance curve 0.5 defines the boundary between immature and mature organic matter. It roughly corresponds to TMAX in the $430-435^{\circ} \mathrm{C}$ range for organic materials of types II and III. The area between curves 0.5 and 1.0 defines the "oil window," i.e., the zone where the main genesis of liquid hydrocarbons occurs. Following curve 1.0 the zone for the formation of condensate and wet gas is found and following curve 2.0, dry gas (Espitalié and Deroo, in press).

\section{Results}

The first requirement for using the TMAX data is an organic carbon content of more than $0.20 \%$. The second requirement depends on the Production Index (PI) of pyrolysis (Espitalié et al., 1977) i.e., the ratio of free hydrocarbons (peak S1) to total hydrocarbons (peaks S1 + S2) expelled during pyrolysis (Appendix Tables 1-5). 


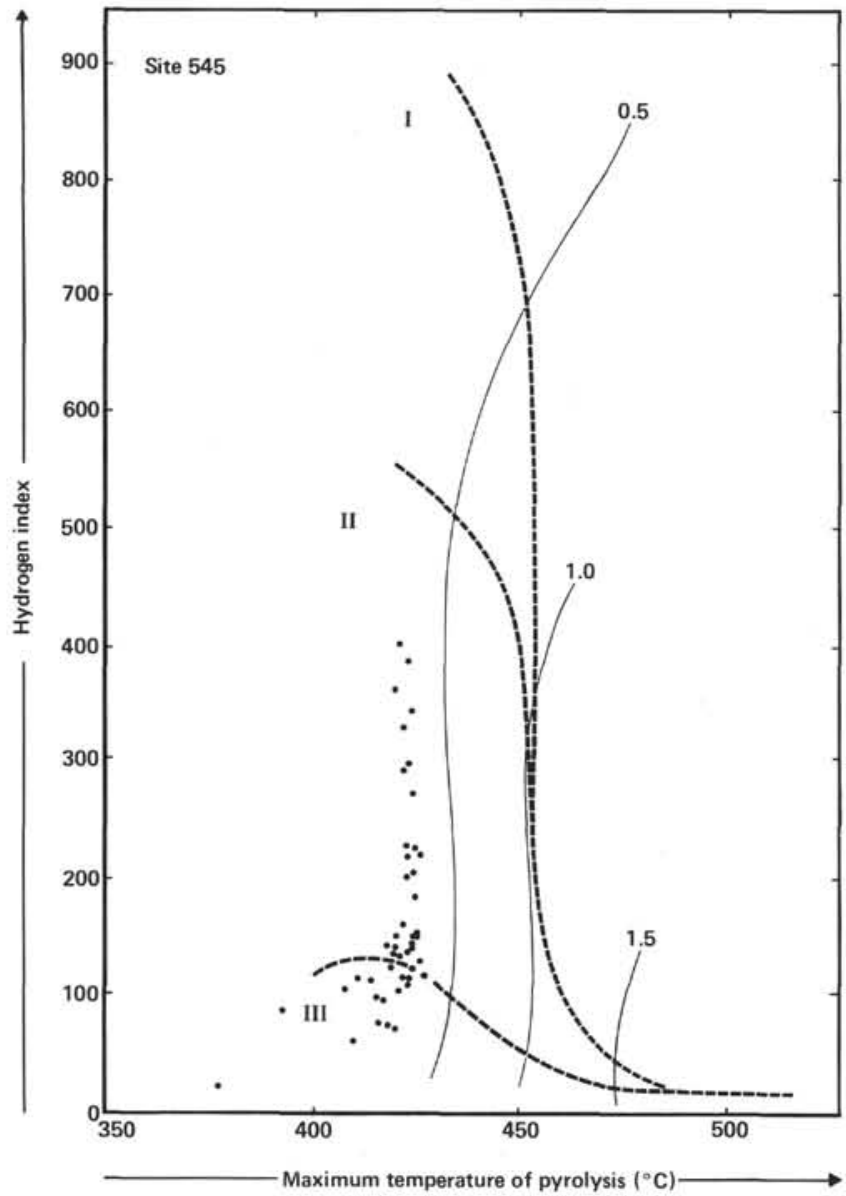

Figure 6. Hydrogen indices versus pyrolysis peak temperatures (TMAX), Site 545.

Thus, the TMAX for the shallow buried organic material, which corresponds to an anomalously large PI of $0.25+$ due to a high number of natural organic molecules in the S1 peak and to a low organic carbon content $(<0.20 \%)$, will be disregarded (Figs. $2-5$ ).

\section{Site 544}

There are no significant TMAX data for Holes 544A and 544B (Appendix Table 1).

\section{Site 545}

The ranges of TMAX observed along the hole are as follows: $420-421^{\circ} \mathrm{C}$ at the bottom of the Neogene series (Unit II) for depths of $217-247 \mathrm{~m}$; and $411-427^{\circ} \mathrm{C}$ for the Cretaceous series (Unit III) for depths between 255 and $433 \mathrm{~m}$, then, $393-424^{\circ} \mathrm{C}$ for the deeper part between 436 and $520 \mathrm{~m}$ (Figs. 6, 8; Appendix Table 2).

The vertical distribution of TMAX, according to $5^{\circ} \mathrm{C}$ wide classes versus depth (Fig. 8), shows, following the two values within Neogene Unit II in the $420-424^{\circ} \mathrm{C}$ class, a mode localized in the same $420-424^{\circ} \mathrm{C}$ class for the three Cretaceous intervals of depth. Also, an increase of the adjacent $425-429^{\circ} \mathrm{C}$ class is observed for the two deeper intervals, from depths of $377-519 \mathrm{~m}$.

In the hydrogen index versus TMAX diagram (Fig. 6), all the plots occur in the area largely below the TMAX

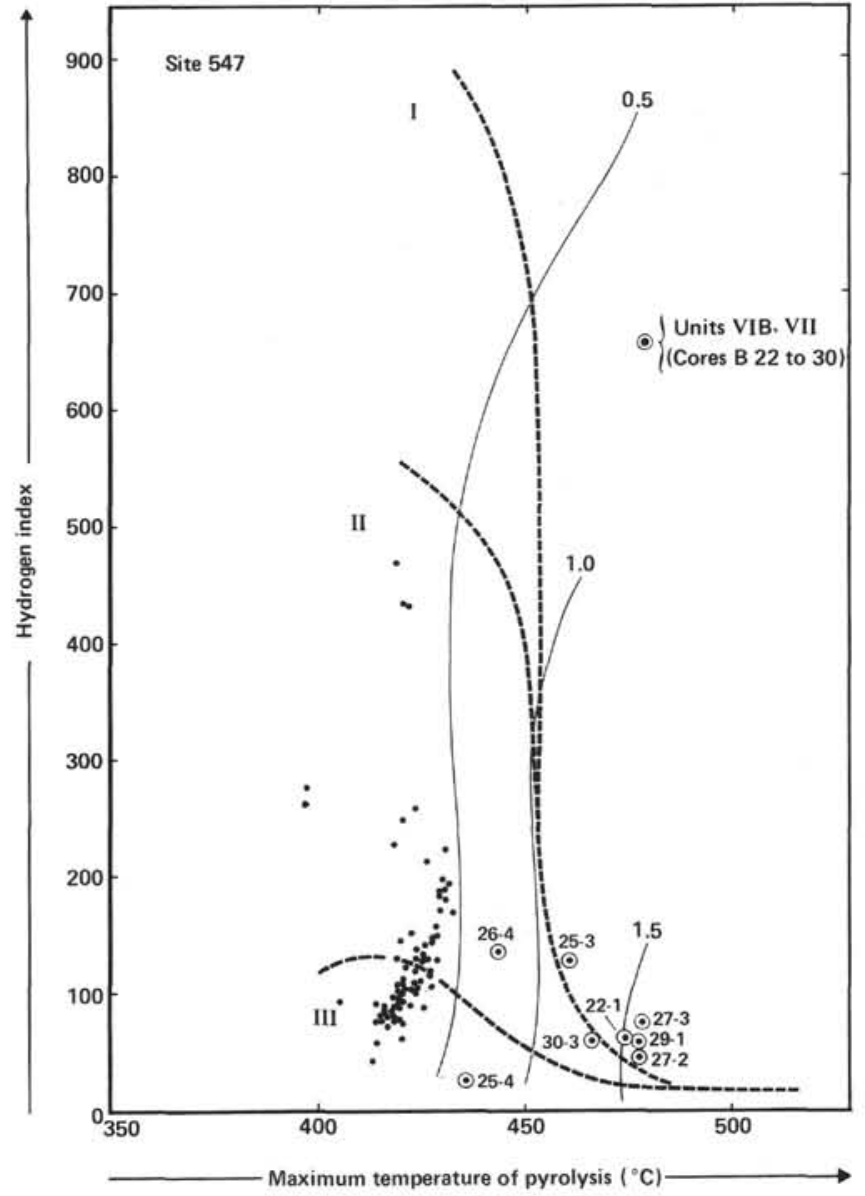

Figure 7. Hydrogen indices versus pyrolysis peak temperatures (TMAX), Site 547.

of $430-435^{\circ} \mathrm{C}$ and the curve of isoreflectance 0.5 , assigning an immature stage of maturation to all the Site 545 samples.

\section{Site 546}

Considering the limits assigned previously for the significance of organic carbon content and production indices (Appendix Table 3) only a few TMAX data can be considered. They are scattered at the bottom of Unit I and along Unit II with a range of $416-427^{\circ} \mathrm{C}$ indicative of immature material. Higher temperatures from $496-550^{\circ} \mathrm{C}$ found at the bottom of Unit II suggest great alteration and/or reworked material.

\section{Site 547}

Within the Cenozoic Units I and II, significant values appear in Subunit IIA. They occur mainly in Units III and IV, ranging from 405 to $424^{\circ} \mathrm{C}$ (Figs. 7, 8; Appendix Table 4). In Cretaceous Unit V, TMAX varies from 414 to $421^{\circ} \mathrm{C}$ in the first hundred meters (Cores $547 \mathrm{~A}-40$ to $547 \mathrm{~A}-51$ ), then from 414 to $427^{\circ} \mathrm{C}$ for the following hundred meters (Cores 547A-52 to 547A-62), and from 413 to $433^{\circ} \mathrm{C}$ for the bottom hundred meters (Cores 547A-63 to 547B-6). For Early Jurassic/late Triassic Unit VII, two ranges are observed from 436 to $444^{\circ} \mathrm{C}$ and 461 to $479^{\circ} \mathrm{C}$, respectively. 

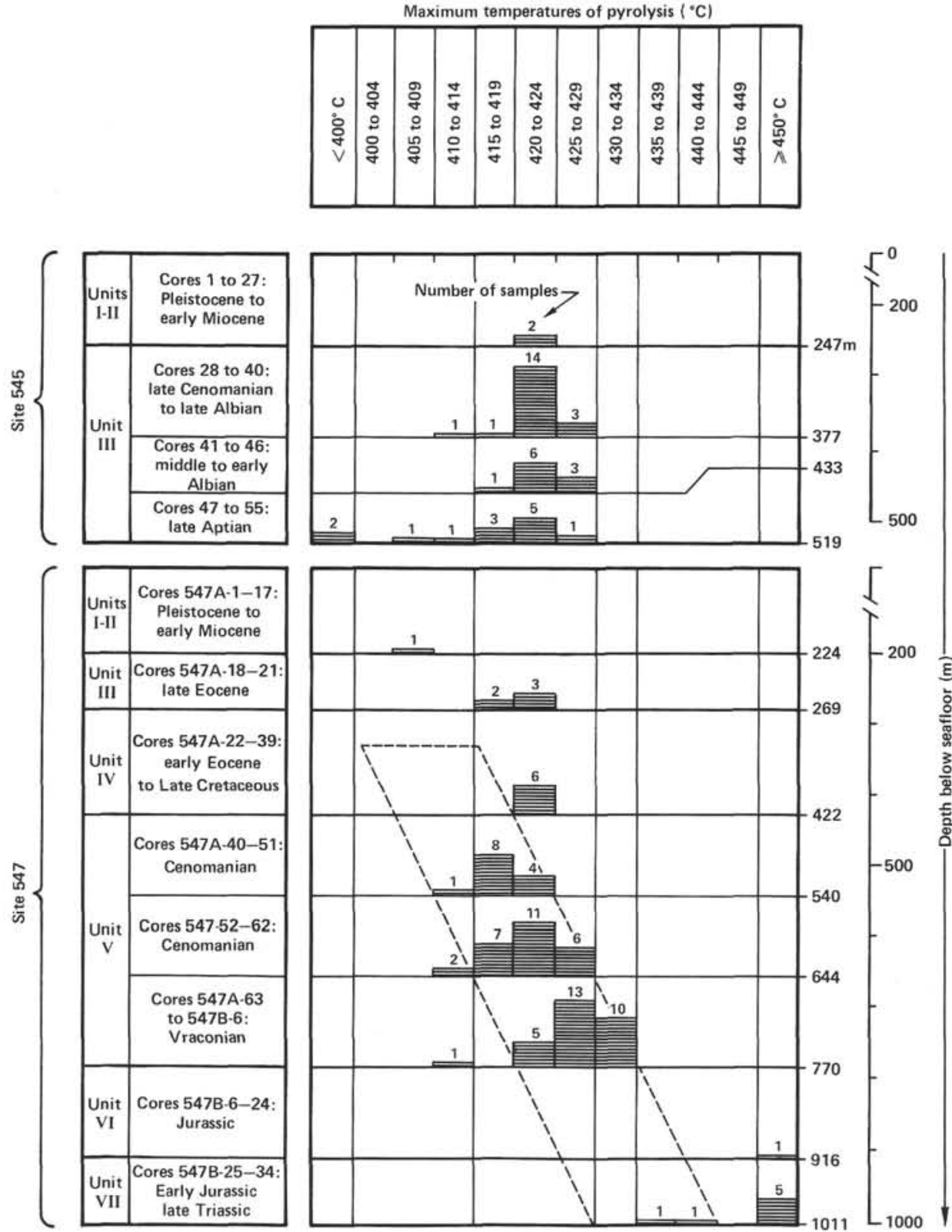

Figure 8. Pyrolysis assays. Vertical distribution of maximum temperature (TMAX) classes for Sites 545 and 547 .

When the vertical distribution of TMAX according to $5^{\circ} \mathrm{C}$-wide classes (Fig. 8 is considered), a progressive shift of the mode is observed along the Cretaceous Unit $\mathrm{V}$ as depths increase. This shift encompasses the 415-419 and $425-429^{\circ} \mathrm{C}$ classes. The same trend extends into Early Jurassic/late Triassic Unit VII for samples of the $435-444^{\circ} \mathrm{C}$ range. It does not extend to the overlying Units IV and III, that mode being higher $\left(420-424^{\circ} \mathrm{C}\right)$ than the adjacent part of Unit V. Such anomalies, especially for Unit IV, suggest reworked material.

In the hydrogen index versus TMAX diagram (Fig. 7), most of the points for Units I to V are clustered in the immature area. The isoreflectance curve 0.5 , at the beginning of the oil window, is only reached for samples of Cores 547A-70 to 547A-73 and 547B-4 and 547B-5 at the bottom of Unit V for depths of 716-770 m. Only a few samples (Sections 547B-25-4 and 547B-26-4) occur in the oil window and they belong to Unit VII. The other samples of the same unit are more mature: the range of TMAX $\left(461-479^{\circ} \mathrm{C}\right)$ depends on an advanced stage of maturation (PR $>1$ and 1.5). Such a stage, which would be anomalously high for this burial depth, should be due to recycled mature organic matter.

\section{Summary}

Within Site 547, immature organic material occurs throughout the $700 \mathrm{~m}$ of Cenozoic and Cretaceous rocks penetrated. Reworked material is found in the Eocene and the Paleocene sections. The oil window should be reached in the Jurassic beyond a depth of $770 \mathrm{~m}$. 


\section{Petroleum Potential}

Total hydrocarbons (S1 + S2) (Espitalié et al., 1977) expelled during pyrolysis represent the petroleum potential, expressed as kilograms of hydrocarbons per metric ton or rock $(\mathrm{kg} / \mathrm{t})$. Five classes were considered as follows: very good, more than $20 \mathrm{~kg} / \mathrm{t}$; good, 5.01 to 20.00 ; medium, 2.01 to 5.00 ; low, 0.51 to 2.00 ; and very low, 0.50 and less.

\section{Site 544}

In Hole 544A, very low to low petroleum potentials $(0.08-0.81 \mathrm{~kg} / \mathrm{t})$ were found within Neogene Unit I and a low potential $(0.83)$ was found for the Jurassic sample of Unit IV. In Hole 544B, very low potentials (0.12-0.37 $\mathrm{kg} / \mathrm{t}$ ) also characterize Unit I. (Fig. 2, Appendix Table 1)

\section{Site 545}

Neogene Units I and II reveal very low petroleum potentials $(0.14-0.41 \mathrm{~kg} / \mathrm{t})$ except at the top and bottom where low potentials are present, $0.59-0.89 \mathrm{~kg} / \mathrm{t}$, at the top of Subunit IA and $0.73-1.37 \mathrm{~kg} / \mathrm{t}$, at the bottom of Unit II (Fig. 3, Appendix Table 2). Within Unit III of Cretaceous age, low potentials $(0.41-1.44 \mathrm{~kg} / \mathrm{t})$ again characterize the interval from Cores 28 to 33 . Low to medium contents $(1.46-4.71 \mathrm{~kg} / \mathrm{t})$ define the interval from Cores 34 to 45 except at the bottom where good potentials (6.13-17.12 kg/t) occur. For the interval from Cores 45 to 55 , medium to low potentials $(0.88-2.61 \mathrm{~kg} / \mathrm{t})$ are observed within the early to middle Albian section at the top whereas very low to low potentials define the various sequences of late Aptian (Gargasian) age at the bottom.

In general, very low or low potentials related to carbonate-rich deposits are found along the whole Neogene and Cretaceous sections. The only interval with very good petroleum potential occurs during the middle Albian for Cores 41 to 42 .

\section{Site 546}

Very low potentials (less than $0.20 \mathrm{~kg} / \mathrm{t}$ ) are found within Units I and II except for the bottom of the latter unit where some low contents $(0.68-0.93 \mathrm{~kg} / \mathrm{t})$ are present (Fig. 4, Appendix Table 3).

\section{Site 547}

Within Cenozoic Units I, II, and IV, the petroleum potential is generally very low $(0.06-0.57 \mathrm{~kg} / \mathrm{t})$. Good potentials $(6.9-15.8 \mathrm{~kg} / \mathrm{t})$ characterize Unit III except at the bottom where low potentials $(0.88-1.73 \mathrm{~kg} / \mathrm{t})$ prevail (Fig. 5, Appendix Table 4). For Cretaceous Unit V, a progressive enrichment is observed ranging from 0.17 at the top to $1.19 \mathrm{~kg} / \mathrm{t}$ at the bottom. Rich interlayers occur with content increasing from 1.04 to $1.55 \mathrm{~kg} / \mathrm{t}$ in the upper part (Core 547B-5). Very low potentials $(0.10-$ $0.57 \mathrm{~kg} / \mathrm{t}$ ) occur within Jurassic Unit VII.

\section{Summary}

Very low petroleum potential is characteristic of Site 547 within the Cenozoic and the Cretaceous sections except for the very good potential evident in the late Eo- cene interval and some slight enrichments in the late $\mathrm{Al}$ bian sections just above the Jurassic deposits.

\section{Nature of the Organic Matter}

\section{Site 544}

Immature organic matter is found in all of Unit I of Holes 544A and 544B as attested to by anomalously high production indices (PI: 0.37 and higher) (Appendix Table 1). This organic matter primarily yields natural hydrocarbons and nonhydrocarbons (peak S1) that are not yet representative of true petroleum compounds. Moreover, these indigenous components generate large quantities of $\mathrm{CO}_{2}$ when pyrolyzed as shown by the high oxygen indices. Such material will be considered in this report as undifferentiated organic matter.

\section{Site 545}

Except for the immature material within the first $230 \mathrm{~m}$ cored of Pleistocene to middle Miocene age, all organic matters examined from early Miocene and Cretaceous belong either the marine organic matter that was altered during deposition or to an alternation of well-preserved and highly altered marine organic matter (Fig. 9, Appendix Table 2). Nonmarine organic matter is only detected at the base of the late Aptian (Gargasian) sequence.

When the hydrogen index (HI) versus the oxygen index (OI) is plotted (Fig. 9), it is seen that low OI are related to large $\mathrm{HI}$ and low $\mathrm{HI}$ to large $\mathrm{OI}$. Thus, the data for Site 545 are distributed in an area extending just beyond the reference paths of types II and III. This distribution is commonly observed when well-preserved organic matter is progressively altered by oxidation (Deroo et al., in press), oxygenated organic compounds developing at the expense of the hydrogenated compounds.

Results obtained from kerogen lead us to propose the following hypothesis. The distribution of points observed in the diagram of HI versus OI (Fig. 9) depends on the proportions of pure marine organic matter and oxidized matter in the samples. In the present case, the evidence for oxidation includes burrows within Unit III on both sides of the contact between Cenomanian and Albian deposits as shown in Cores $\mathbf{3 0}$ to $\mathbf{3 7}$ and present abundantly in Cores 38 to 55. As no immature organic matter of type III was apparent, except for Sample 545-37-2, $42 \mathrm{~cm}$, the oxidized material probably originates from alteration of marine organic matter.

Returning to Figure 9, from the top to the bottom of the hole, undifferentiated organic matter $(\mathrm{HI}=106$ and less; OI $=478+$ ) characterizes Unit $\mathrm{I}$ and the upper part of Unit II. At the bottom of Unit II, during the early Miocene, some altered marine organic matter occurs $(\mathrm{HI}=104$ to 136 ; $\mathrm{OI}=262$ to 330$)$. Most of the samples in Subunits III-A and III-B (Cenomanian to late Aptian) correspond to altered marine organic matter $(\mathrm{HI}=<200$; $\mathrm{OI}=200\rangle)$ with low organic carbon content. Well-preserved marine organic matter is found within cores 37 to 44 of Albian age in Subunit IIIB. Only two samples (545-50-6, $56 \mathrm{~cm}$ and $545-55, \mathrm{CC}, 16 \mathrm{~cm})$ correspond to an altered nonmarine type III. The low 


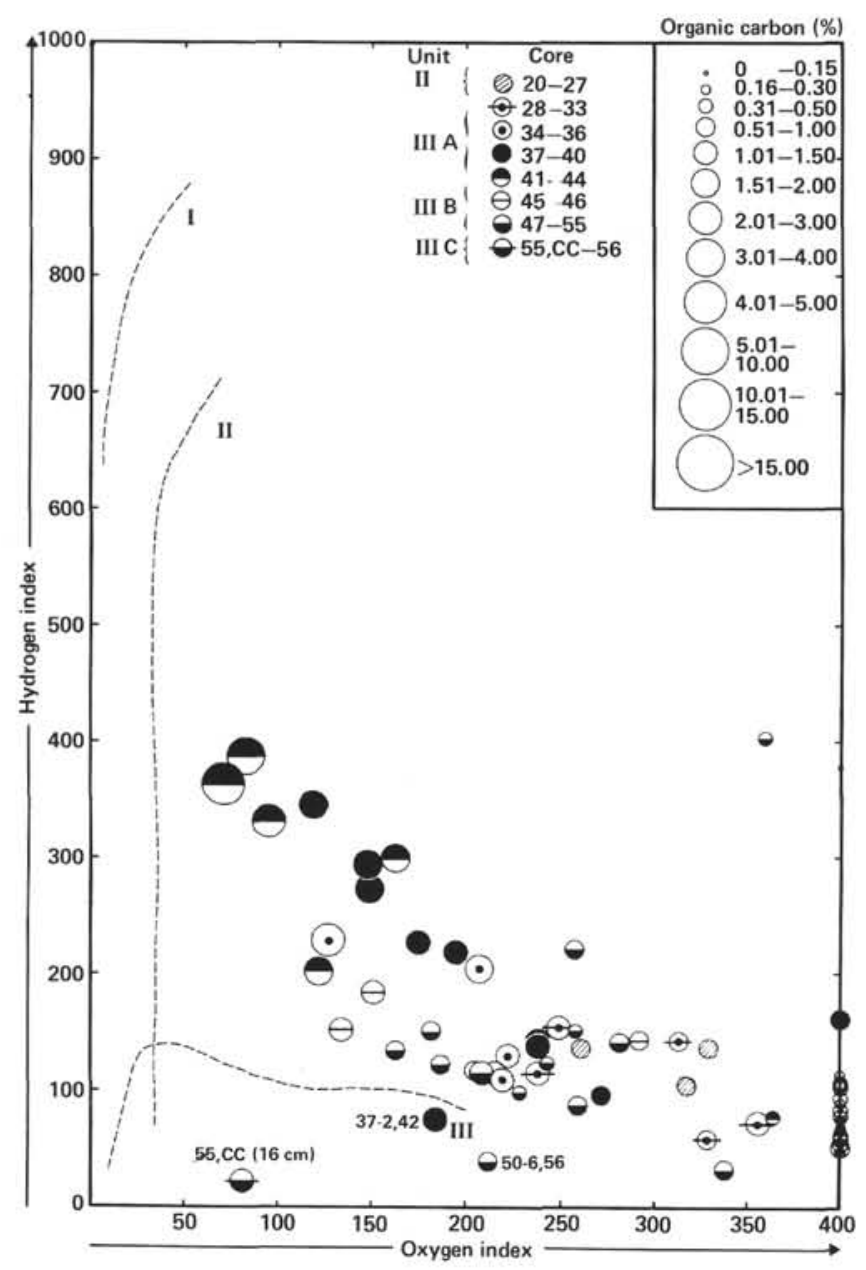

Figure 9. Hydrogen index versus oxygen index, Site 545. Cores 20 to 27, middle to early Miocene; Cores 28 to 33 , late to middle Cenomanian; Cores 34 to 36 , early Cenomanian; Cores 37 to 38 , late Albian (Vraconian); Cores 39 to 40, late Albian; Cores 41 to 44, middle Albian; Cores 45 to 55, middle Albian to late Aptian; and 545-55, CC to Core 56, early late Aptian.

HI (22 and 39) of the samples suggest severe oxidation of immature continental organic matter.

\section{Site 546}

At Site 546 undifferentiated organic matter with very high OI $(754+)$ characterizes the Neogene Unit I (Fig. 10, Appendix Table 3). In Unit II, one sample at interval 546-17-3, $22 \mathrm{~cm}$ corresponds to altered marine material $(\mathrm{HI}=119 ; \mathrm{OI}=239)$. For the other samples of Unit II, TMAX $\left(488-550^{\circ} \mathrm{C}\right)$ infers an advanced stage of maturation incompatible with the low burial depth. Thus, reworking can be proposed for them.

\section{Site 547}

Undifferentiated organic matter occurs within the Neogene Units I and II (Figs. 11, 12; Appendix Table 4). Marine organic matter, which characterizes the Eocene Unit III, is well-preserved for the organic carbon rich levels of Sections 547A-19-1, 547A-20-1, 547A-20-4, and $547 \mathrm{~A}-21-2(\mathrm{HI}=258-471 ; \mathrm{OI}=108-126)$. It is mixed

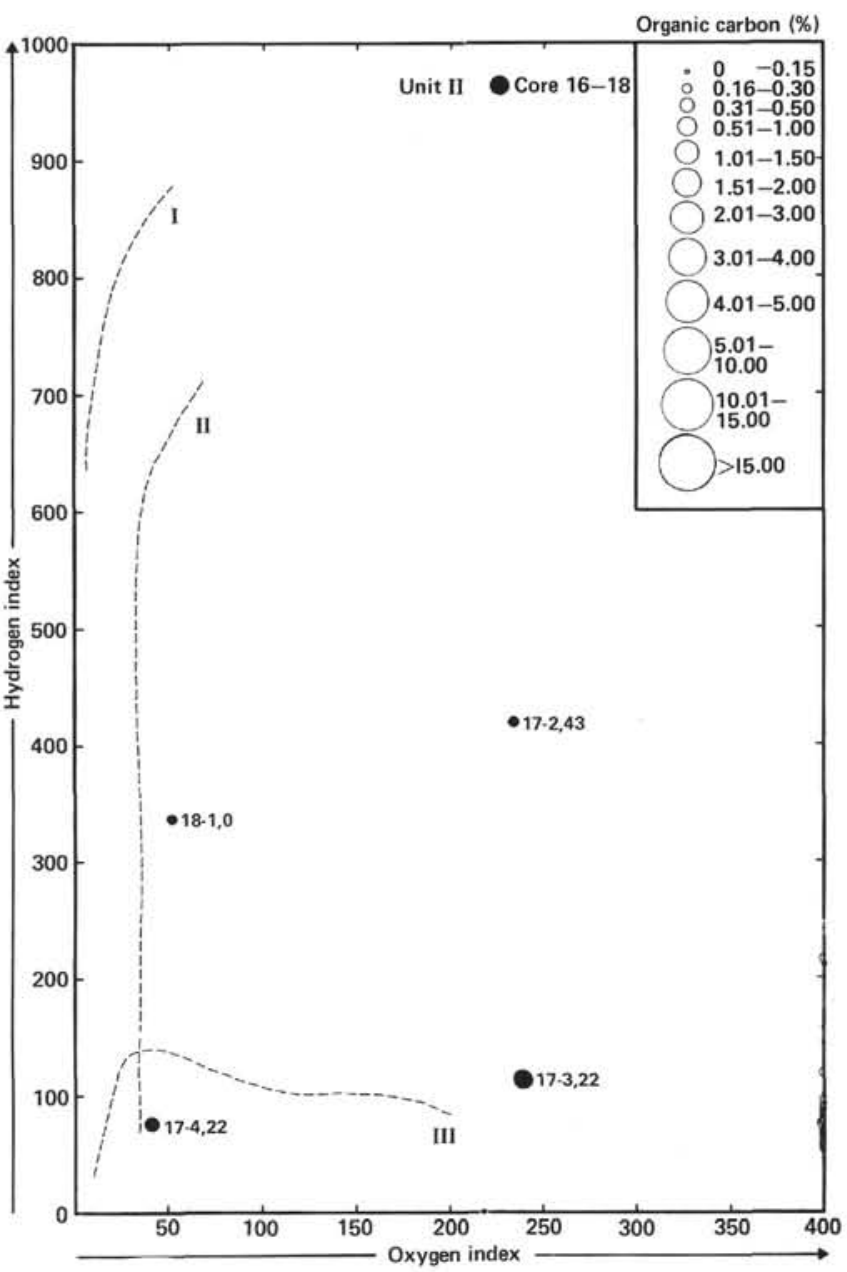

Figure 10. Hydrogen index versus oxygen index, Site 546.

with oxidized marine organic matter in Sections 547A$19-1,547 \mathrm{~A}-21-4$, and 547A-21-6 $(\mathrm{HI}=50-227$; OI $=$ 274-304). Undifferentiated organic matter characterizes Unit IV of early Eocene to Paleocene age, except for Samples 547A-34-3, 84 and 547A-39-1, $29 \mathrm{~cm}$ where some marine organic matter occurs. For Cretaceous Unit $\mathrm{V}$, oxidized organic matter of marine origin predominates over well-preserved material throughout the Cenomanian and Albian (Cores 547A-40 to 547A-68). Slight enrichments of well-preserved marine organic matter is observed downward from Core 547A-67 to Core 547B-5 at the bottom. In Jurassic Unit VI according to analyses on board, undifferentiated organic matter was found for the sample of Subunit VIA, mixed or not with marine organic matter in Subunit VIB. Some nonmarine organic matter occurs in Section 547B-22-1 (Fig. 12). Well-preserved marine organic matter characterizes a thin black shale at interval 547B-20:1, 13 (on board analysis). In Jurassic/Triassic Unit VII, marine organic matter is either altered (intervals 547B-25-3, 100; 547B-26-2, 102; 547B-27-3, 112; and 547B-30-4, 50) or mixed with a residual organic matter through interval 547B-25-3, 93 and mixed with nonmarine organic matter for interval 547B-26-4, 62. Other samples reveal ei- 


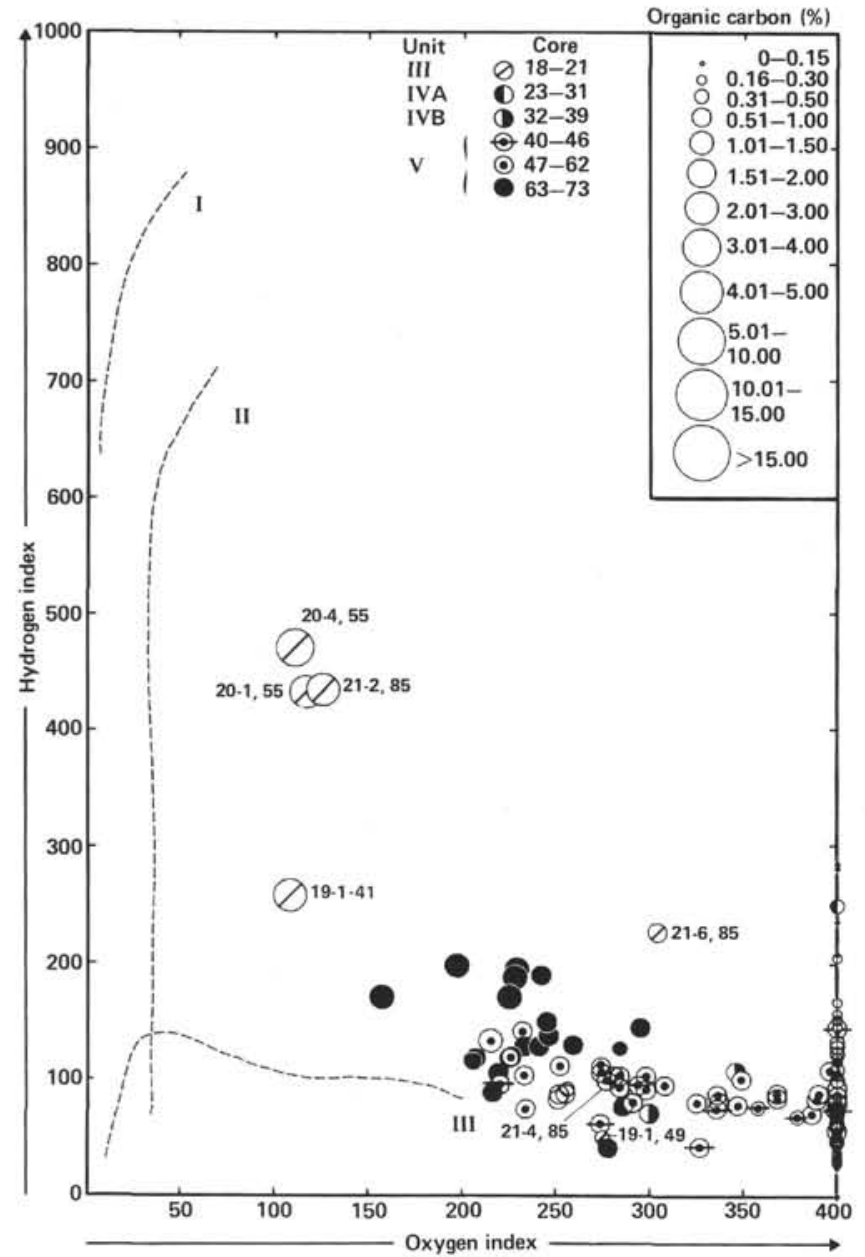

Figure 11. Hydrogen index versus oxygen index, Hole 547A. Cores 18 to 21, late Eocene; Cores 23 to 31 , early Eocene to early Paleocene; Cores 32 to 39, early Paleocene and Late Cretaceous; Cores 40 to 73 , late or middle Cenomanian to late Albian.

ther nonmarine organic matter at 547B-29-1, 112 and 547B-30-7, 82 or undetermined organic matter for Samples 547B-27-2, 64 and 547B-29-1, 36.

\section{Summary}

Organic matter of continental origin was found in red beds of Early Jurassic to late Triassic age in Hole 547B. Marine organic matter indications and one organic carbon rich layer are found higher up in the Jurassic. Altered organic matter of marine origin predominates throughout the Cretaceous at each site. The alteration increases from bottom to top, for example, in Hole 547A from late Albian to Cenomanian. For comparison, the hydrogen index versus oxygen index for Site 370 is presented in Figure 13.

Well-preserved marine organic matter mixed with an altered organic matter is present throughout the late Aptian and Cenomanian cored at Site 545. Organic carbon rich levels define the series to be of early to middle Albian age. Such levels are scattered in the late Albian (Vraconian) and Cenomanian while the altered organic matter related to burrowing is subordinate or even absent.

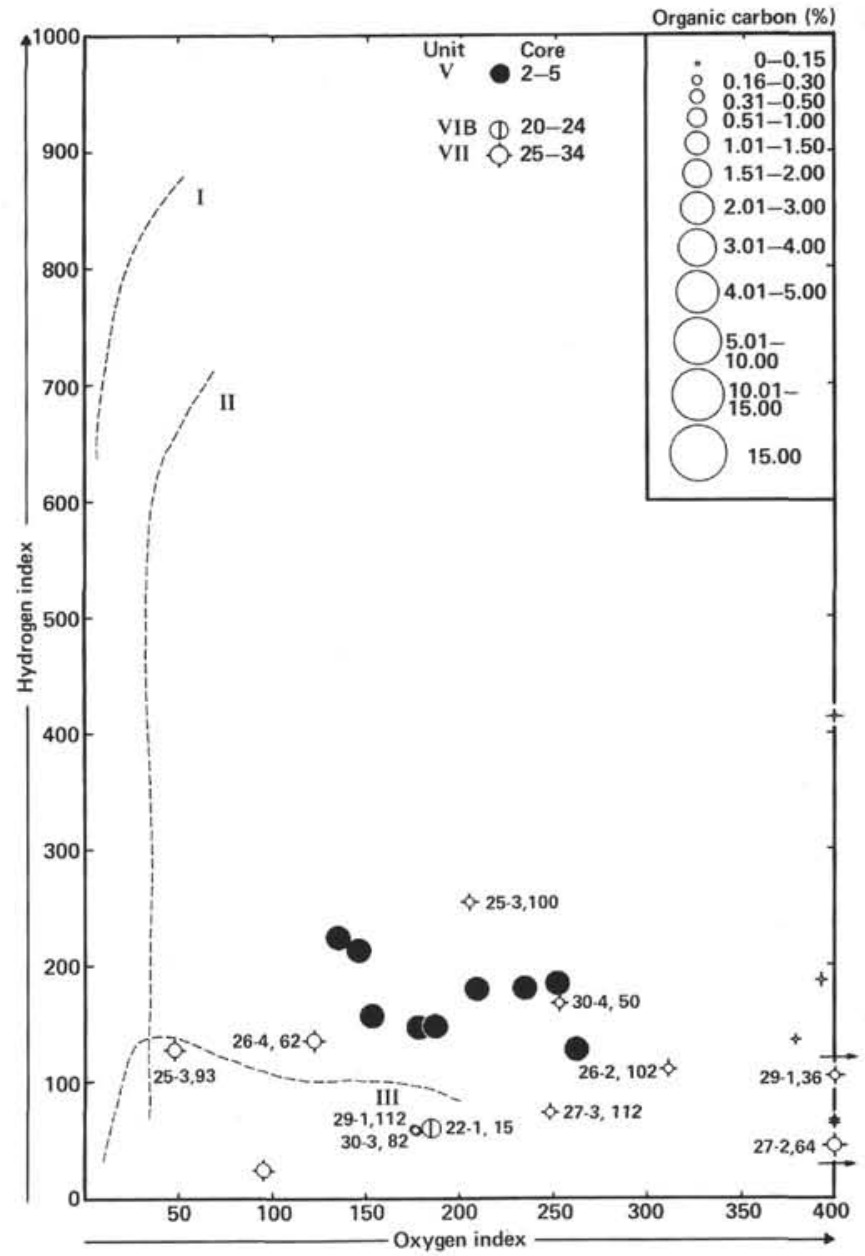

Figure 12. Hydrogen index versus oxygen index, Hole 547B. Cores 2 to 5 , late Albian; Cores 20 to 24 , Pliensbachian to Sinemurian; and Cores 25 to 34, Early Jurassic/late Triassic.

Generally, the carbonate series of Cenozoic age reveals low contents of organic carbon and undetermined organic matter. An exception is found in Hole 547A as the slumps in the late Eocene, Unit III, contain a typical marine matter that is organically rich. Such organic matter is similar to the richest levels observed in the middle to early Albian series at Site 545. During the late Eocene, these slumps were displaced from the upper part of the continental slope and are composed of Cretaceous and early Tertiary material. Such an explanation was invoked by Cornford (1979) and Deroo et al. (1979) at Hole 397 of Leg 47A for similar sediments rich in organic matter. These sediments were cored at the bottom of early Miocene shales which rest directly upon Hauterivian shales and mudstones. Independently of sedimentological evidence, geochemical characteristics observed in Site 547 for the Eocene samples of Unit III allow us to conclude that reworked organic matter was recycled from Cretaceous material.

\section{Kerogen Study}

Ten samples provided by the Organic Geochemistry Panel were selected from different units of Sites 545 and 


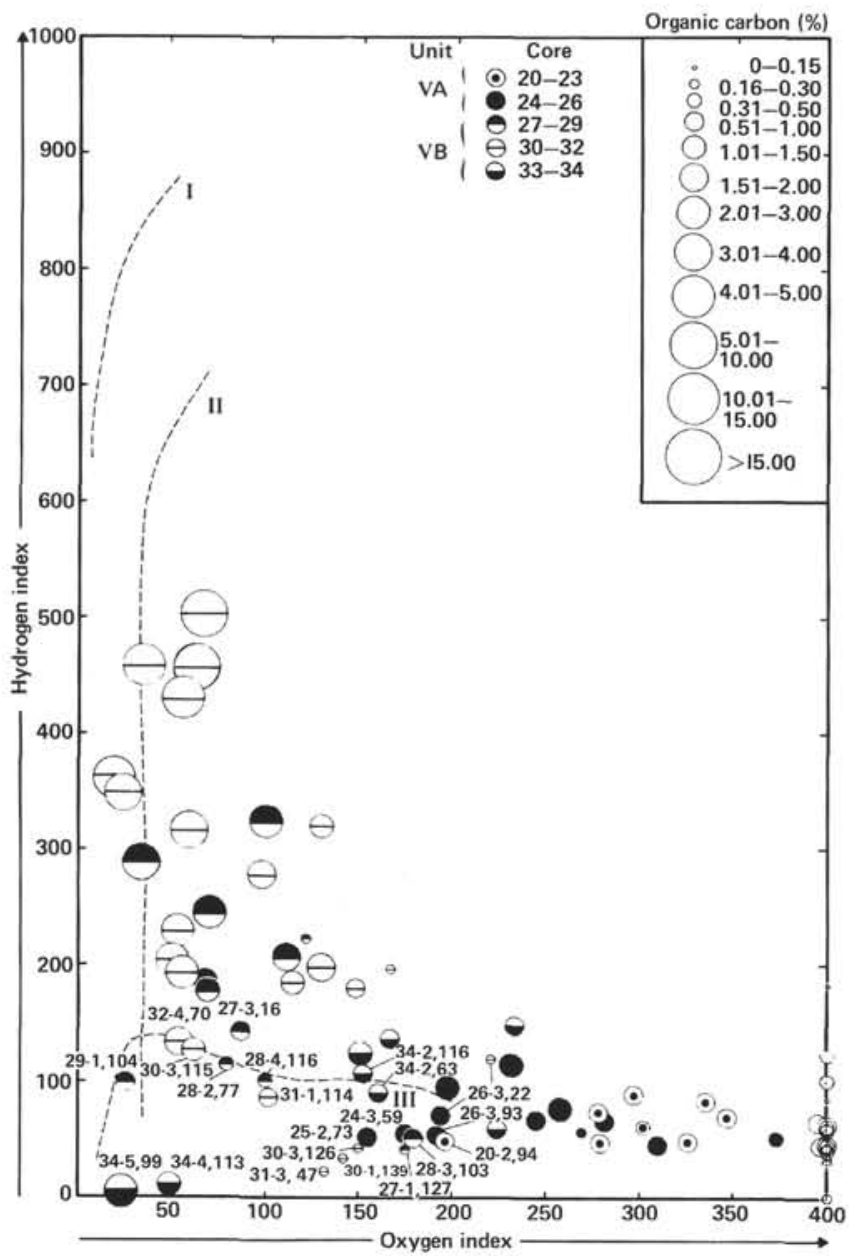

Figure 13. Hydrogen index versus oxygen index, Site 370 . Cores 20 to 23, early Cenomanian; Cores 24 to 26, late Albian; Cores 27 to 32 , middle to early Albian; and Cores 33 to 34, early Aptian to late Barremian.

547 and prepared for elemental analysis $(\mathrm{C}, \mathrm{H}, \mathrm{N}, \mathrm{O}, \mathrm{S}$, and $\mathrm{Fe}$ ) of the kerogen concentrations (Table 1). This analysis reveals 22-32 wt. \% pyrite equivalent in Site 545 and 1-53 wt. \% in Site 547. The H/C and O/C ratios in Table 1 are plotted on a Van Krevelen diagram (left side of Fig. 14) and compared to the Rock-Eval data for the same samples (right side of Fig. 14), according to the three reference evolution paths for types I, II, and III kerogens of ancient sediments (Tissot et al., 1974).

As indicated on both graphs, an immature stage can be assigned to all the samples of Sites 545 and 547. In Site 545 , a group of three points clusters halfway between path II and path III and the fourth point near path III. In Site 547, a single point is localized near and below the limit for kerogen: this sample contains degraded kerogen and is considered residual organic material (Tissot et al., 1979). Four of the five other points are distributed along a trend of increasing $\mathrm{O} / \mathrm{C}$ ratios (0.16-0.26) while $\mathrm{H} / \mathrm{C}$ ratios decrease slightly (1.231.15). The same trend was observed for pyrolysis of the rock samples (right side of Fig. 14). This has been observed for two kerogens from Section 511-59-3 in DSDP Leg 75 (Deroo et al., in press) and for kerogens of the
Table 1. Elemental composition of kerogens.

\begin{tabular}{|c|c|c|c|c|c|c|c|c|c|c|}
\hline \multirow{2}{*}{$\begin{array}{c}\text { Sample } \\
\text { (interval in } \mathrm{cm} \text { ) }\end{array}$} & \multirow{2}{*}{$\begin{array}{c}\text { Depth below } \\
\text { seafloor } \\
\text { (m) }\end{array}$} & \multicolumn{6}{|c|}{ Composition (wt.\%) } & \multirow{2}{*}{$\begin{array}{l}\text { Ashes } \\
\text { (wt.\%) }\end{array}$} & \multicolumn{2}{|c|}{ Atomic ratio } \\
\hline & & c & $\mathrm{H}$ & $\mathrm{N}$ & 0 & $s$ & $\mathrm{Fe}$ & & $\mathrm{H} / \mathrm{C}$ & $\mathrm{O} / \mathrm{C}$ \\
\hline \multicolumn{11}{|l|}{ Hole 545} \\
\hline $\begin{array}{l}34-2,120-130 \\
40-3,120-130 \\
43-4,135-145\end{array}$ & $\begin{array}{l}315.20 \\
373.70 \\
403.85\end{array}$ & $\begin{array}{l}36.1 \\
44.7 \\
42.3\end{array}$ & $\begin{array}{l}2.8 \\
4.6 \\
4.4\end{array}$ & $\begin{array}{l}1.5 \\
1.8 \\
1.6\end{array}$ & $\begin{array}{l}15.8 \\
13.1 \\
12.1\end{array}$ & $\begin{array}{l}13.8 \\
18.8 \\
21.3\end{array}$ & $\begin{array}{l}10.3 \\
13.7 \\
15.1\end{array}$ & $\begin{array}{r}19.8 \\
3.3 \\
3.4\end{array}$ & $\begin{array}{l}0.95 \\
1.23 \\
1.24\end{array}$ & $\begin{array}{l}0.33 \\
0.22 \\
0.21 \\
0.23\end{array}$ \\
\hline 55-5, $120-130$ & 519.20 & 43.8 & 4.5 & 1.5 & 13.5 & 18.7 & 14.8 & 3.3 & 1.23 & \\
\hline \multicolumn{11}{|l|}{ Hole 547A } \\
\hline $\begin{array}{l}20-1,55-56^{\mathrm{a}} \\
43-2,120-130 \\
58-4,120-125 \\
73-3,120-125\end{array}$ & $\begin{array}{l}251.05 \\
462.20 \\
607.70 \\
739.20\end{array}$ & $\begin{array}{l}56.4 \\
27.6 \\
38.4 \\
48.2\end{array}$ & $\begin{array}{l}5.9 \\
2.7 \\
3.7 \\
4.4\end{array}$ & $\begin{array}{l}2.6 \\
1.2 \\
1.8 \\
2.1\end{array}$ & $\begin{array}{l}16.5 \\
9.8 \\
13.0 \\
12.4\end{array}$ & $\begin{array}{l}10.6 \\
28.2 \\
20.7 \\
13.6\end{array}$ & $\begin{array}{r}4.7 \\
24.9 \\
15.2 \\
9.1\end{array}$ & $\begin{array}{r}3.3 \\
5.6 \\
7.2 \\
10.2\end{array}$ & $\begin{array}{l}1.25 \\
1.16 \\
1.15 \\
1.09\end{array}$ & $\begin{array}{l}0.22 \\
0.27 \\
0.25 \\
0.19\end{array}$ \\
\hline \multicolumn{11}{|l|}{ Hole 547B } \\
\hline $\begin{array}{l}5-6,113-123 \\
25-4,0-5\end{array}$ & $\begin{array}{l}769.63 \\
937.00\end{array}$ & $\begin{array}{l}50.6 \\
63.4\end{array}$ & $\begin{array}{l}5.2 \\
2.8\end{array}$ & $\begin{array}{l}2.1 \\
1.2\end{array}$ & $\begin{array}{l}10.9 \\
13.0\end{array}$ & $\begin{array}{r}15.3 \\
0.8\end{array}$ & $\begin{array}{r}10.7 \\
0.6\end{array}$ & $\begin{array}{r}5.3 \\
18.2\end{array}$ & $\begin{array}{l}1.23 \\
0.52\end{array}$ & $\begin{array}{l}0.16 \\
0.15\end{array}$ \\
\hline
\end{tabular}

lower Toarcian in the Paris basin. Larger $\mathrm{O} / \mathrm{C}$ ratios were obtained for weathered samples from outcrops in the Paris basin, the weathering enriched the organic matter with oxygenated compounds at the expense of the hydrogenated ones. Such a trend was attributed to an alteration path, quite distinct from the thermal evolution path, similar to the one suggested here.

In Site 545, the group of three points clustered halfway between paths II and III are in the same relative position as the Eocene Sample $(547 \mathrm{~A}-20,55 \mathrm{~cm})$. The alteration trend clearly expressed at Site $547 \mathrm{~A}$ for both pyrolysis and kerogen data was not observed at Site 545 .

\section{Chloroform Extract Study}

The extracts collected from 17 selected samples (Tables 2, 3) represent $0.05-0.20$ wt.\% of rock in Site 545 and $0.06-0.28$ wt. $\%$ in Site 547 . This corresponds to $0.8-1.5 \%$ of extract to total organic carbon in Site 545 and $1.1-2.3 \%$ for Site 547 . As is usually found in DSDP sediments, polar compounds of high molecular weight predominate in the extract. Thus, the hydrocarbons are represented (1) by $15-23 \%$ of the total extract for the Miocene and the Eocene samples, respectively, in Sites 545 and 547 ; (2) 7-18\% for the Cretaceous extracts at Site 545 and $11-25 \%$ for the extracts of Site 547 ; and (3) $29 \%$ for the Jurassic extract at Site 547.

Four extracts at Site 545 and six at Site 547 were then selected for capillary gas chromatography (GC) studies (Tables 2,3). The GC analysis of saturates + unsaturates reveals comparable chromatograms for the analyzed samples at Site 545 of Cenomanian, late Albian (Fig. 15B), early to middle Albian, and late Aptian (Fig. 15C) ages. Predominance of $\mathrm{C}_{15}$ and $\mathrm{C}_{17}$ normal alkanes in the $\mathrm{C}_{15}$ to $\mathrm{C}_{35}$ distribution and the occurrence of sterane/sterene, triterpane/triterpene molecules in the $n-\mathrm{C}_{27}+$ range (Fig. 15B) imply a marine origin for the extracts. Predominance of odd numbered molecules in the $n$-C23 to $n$-C35 range (Fig. 15A-D) indicates immature material. In the extract of the composite sample (Cores 547A-20 and 547A-21) of late Eocene age, the $n$-C14 to $n$-C17 mode is so prominent that the $n-\mathrm{C}_{27}+$ alkanes are barely detected (Fig. 15A). The chromatograms of Site 547 for Cenomanian extracts look similar those of Site 545 (Fig. 15). For Vraconian and late Al- 

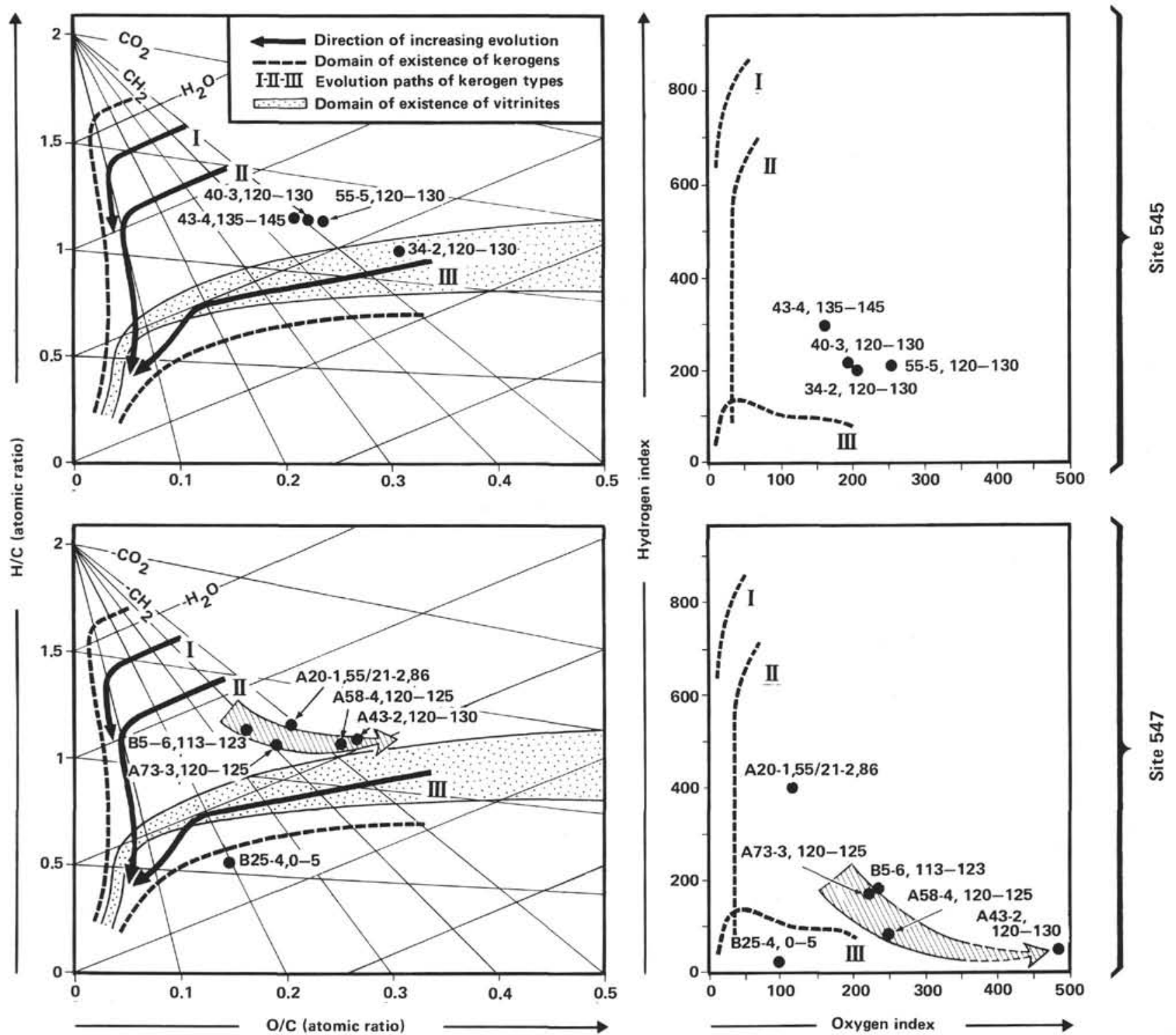

Figure 14. H/C versus O/C diagram of kerogens compared with HI versus OI diagram for rock pyrolysis at Sites 545 and 547.

Table 2. Composition of chloroform extracts, Hole 545.

\begin{tabular}{|c|c|c|c|c|c|c|c|}
\hline \multirow[b]{2}{*}{$\begin{array}{c}\text { Samples } \\
\text { (interval in } \mathrm{cm} \text { ) }\end{array}$} & \multirow[b]{2}{*}{$\begin{array}{l}\text { Depth below } \\
\text { seafloor } \\
\text { (m) }\end{array}$} & \multirow[b]{2}{*}{$\begin{array}{c}\mathrm{HCCl}_{3} \\
\text { extract } \\
\text { (wt., mg) }\end{array}$} & \multirow[b]{2}{*}{$\begin{array}{c}\text { Extract } \\
\text { to rock } \\
(\%)\end{array}$} & \multirow[b]{2}{*}{$\begin{array}{c}\text { Extract to } \\
\text { org. carbon } \\
(\%)\end{array}$} & \multicolumn{3}{|c|}{ Thin layer chromatography fractionation } \\
\hline & & & & & $\begin{array}{c}\text { High-molecular } \\
\text {-weight } \\
\text { compounds } \\
(\%)\end{array}$ & $\begin{array}{c}\text { Aromatics } \\
(\%)\end{array}$ & $\begin{array}{c}\text { Saturates + } \\
\text { unsaturates } \\
(\% \%)\end{array}$ \\
\hline $26-1,120-130^{\mathrm{a}}$ & 237.20 & 2.4 & 0.006 & 1.4 & 85 & 0 & 15 \\
\hline $34-2,120-130^{\mathrm{a}}$ & 315.20 & 7.1 & 0.013 & 1.1 & 93 & 1 & 6 \\
\hline $37-2,135-145$ & 343.85 & 8.2 & 0.015 & 1.5 & 84 & 2 & 14 \\
\hline $40-3,120-130^{\mathrm{a}}$ & 373.70 & 6.0 & 0.020 & 1.2 & 89 & 2 & 9 \\
\hline $43-4,135-145^{\mathrm{a}}$ & 403.85 & 6.3 & 0.011 & 0.8 & 93 & $<i$ & 7 \\
\hline $46-4,120-130$ & 432.20 & 2.6 & 0.008 & 0.8 & 82 & 4 & 14 \\
\hline $52-5,120-130$ & 490.70 & 9.1 & 0.005 & 0.9 & 84 & 5 & ii \\
\hline $55-5,120-130^{\mathrm{a}}$ & 519.20 & 5.9 & 0.012 & 1.3 & 92 & $<1$ & 8 \\
\hline
\end{tabular}

bian age extracts, the $n$-alkane distribution begins with a slight $n-\mathrm{C}_{16}$ mode within the $n-\mathrm{C}_{14}$ to $n-\mathrm{C}_{21}$ range (Fig. 15D). This is followed by a flat distribution from $n-\mathrm{C}_{22}$ to $n-\mathrm{C}_{32}$. Similar distributions were observed for immature organic matter of type I in Green River Shales (Tissot et al., 1978). A slight predominance of phytane upon pristane occurs (Fig. 15D). The composite distri- bution for the n-alkanes suggests a mixed contribution of marine type I and type II organic matters. Sterane/ sterene and triterpane/triterpene molecules are again detected. For the older sample analyzed of Jurassic (? Liassic) age, the distribution differs from that of the Cretaceous by the disappearance of the odd predominance, suggesting a more advanced stage of maturation. 
Table 3. Composition of chloroform extracts, Holes 547A and 547B.

\begin{tabular}{|c|c|c|c|c|c|c|c|}
\hline \multirow[b]{2}{*}{$\begin{array}{c}\text { Samples } \\
\text { (interval in } \mathrm{cm} \text { ) }\end{array}$} & \multirow[b]{2}{*}{$\begin{array}{l}\text { Depth below } \\
\text { seafloor } \\
\text { (m) }\end{array}$} & \multirow[b]{2}{*}{$\begin{array}{c}\mathrm{HCCl}_{3} \\
\text { extract } \\
\text { (wt., mg) }\end{array}$} & \multirow[b]{2}{*}{$\begin{array}{l}\text { Extract } \\
\text { to rock } \\
(\%)\end{array}$} & \multirow[b]{2}{*}{$\begin{array}{l}\text { Extract to } \\
\text { org. carbon } \\
\text { (\%) }\end{array}$} & \multicolumn{3}{|c|}{ Thin layer chromatography fractionation } \\
\hline & & & & & $\begin{array}{l}\text { High-molecular } \\
\text {-weight } \\
\text { compounds } \\
(\%)\end{array}$ & $\begin{array}{l}\text { Aromatics } \\
(\% \%)\end{array}$ & $\begin{array}{c}\text { Saturates + } \\
\text { unsaturates } \\
(\%)\end{array}$ \\
\hline \multicolumn{8}{|l|}{ Hole $547 \mathrm{~A}$} \\
\hline $20-1,55-56^{\mathrm{ab}}$ & 251.05 & 1.1 & 0.028 & 1.1 & 77 & 6. & 17 \\
\hline $43-2,120-130^{3}$ & $\begin{array}{l}462.20 \\
519.20\end{array}$ & 3.4 & 0.006 & 1.1 & & 75 & 25 \\
\hline $49-2,120-130$ & 519.20 & 6.4 & 0.011 & 1.5 & & 81 & 19 \\
\hline $\begin{array}{l}58-4,120-125^{a} \\
6-3,140-150\end{array}$ & 607.70 & 3.0 & 0.012 & 1.6 & & 85 & 15 \\
\hline $\begin{array}{l}61-3,140-150 \\
73-3,120-125^{\mathrm{a}}\end{array}$ & 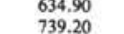 & $\begin{array}{c}13.8 \\
8.9\end{array}$ & 0.012 & 1.9 & & & ${ }_{16}^{15}$ \\
\hline \multirow{2}{*}{\multicolumn{8}{|c|}{ Hole S47B }} \\
\hline & & & & & & & \\
\hline $2-4,120-130$ & 739.70 & 12.8 & 0.016 & 1.2 & & 85 & 15 \\
\hline $5-6,113-123^{a}$ & 769.63 & 10.8 & 0.018 & 1.4 & & 89 & 11 \\
\hline $25-4,0-5^{\mathrm{a}}$ & 937.00 & 2.3 & 0.010 & 2.3 & 71 & 9 & 20 \\
\hline
\end{tabular}

\section{DISTRIBUTION OF ORGANIC MATTER DURING THE EARLY AND MID-CRETACEOUS IN SITES 545 AND 547 COMPARED WITH SITE 370}

Drilling was conducted along the Moroccan platform on DSDP Legs 14, 41, 50, and most recently during Leg 79. Thus, the Mazagan Escarpment edge at Site 545, or a high block structure just below the escarpment on the slope at Sites 544 and 547, can be compared with the basin sediments found at Sites 370 and 416 off the Agadir Canyon.

The vertical distribution of organic matter between Sites 370, 545, and 547 during the early Aptian to early Cenomanian period should be compared. Stratigraphic ages for Site $\mathbf{3 7 0}$ have been revised in the North Atlantic area (Graciansky et al., 1982). For the other sites, ages are based on shipboard data for planktonic foraminifers. Limits for the Albian series are clearly established for the three sites. Vraconian subseries were distinguished from late Albian subseries at Sites 370 and 545, while gravity driven redeposition disturbs the sediments of the same age at Site 547. Early to middle Albian subseries overlie the early Aptian at Site 370 . They are absent at Site 547. At Site 545 they overlie a repeated series of late Aptian (upper late Gargasian and lower late Gargasian) age. It is clear from the HI and OI diagrams (Figs. 9-13) that marine organic matter largely predominates over nonmarine organic mater in the interval from the early Cenomanian to early late Aptian for Sites 547 and 545.

\section{Characterization of Organic Matter}

Nonmarine organic matter, absent at Site 547 , is barely represented at Site 545; for example in 545-37-2, 42 $\mathrm{cm}$ in the Vraconian series it is well preserved; whereas it is altered in the core catcher of Core 545-55 and at 545$50-6,56 \mathrm{~cm}$ in the late Aptian slices (Fig. 9). Nonmarine organic matter, altered or well-preserved, is more largely distributed at Site 370 (Fig. 13). Altered material characterizes the organic matter of several samples (370-31-3, $47 \mathrm{~cm} ; 370-30-3,126 \mathrm{~cm}$; and $370-30-1,139 \mathrm{~cm}$ ) or contributes to its composition (370-32-4, $70 \mathrm{~cm} ; 370-31-1$, $114 \mathrm{~cm} ; 370-30-3,115 \mathrm{~cm}$; 370-29-1, $104 \mathrm{~cm} ; 370-28-4$,
$116 \mathrm{~cm}$; and $370-28-2,77 \mathrm{~cm}$ ) during the early to middle Albian time. Well-preserved nonmarine organic matter occurs in the same interval $(370-28-3,109 \mathrm{~cm}$ and 370 $27-1,127 \mathrm{~cm}$ ). It is also found within the Vraconian/late Albian intervals (370-26-3, $22 \mathrm{~cm}$ and 370-26-3, $93 \mathrm{~cm}$; $370-25-2,73 \mathrm{~cm}$; and $370-24-3,59 \mathrm{~cm})$ and the early Cenomanian interval $(370-20-2,94 \mathrm{~cm})$. Some contribution of nonmarine organic matter also occurs in the early Aptian/late Barremian series; well preserved for Sample 370-34-2, $63 \mathrm{~cm}$ and 370-34-2, $116 \mathrm{~cm}$ and for Samples $370-34-4,113 \mathrm{~cm}$ and 370-34-5, $99 \mathrm{~cm}$ altered, presumably reworked, into calcareous sands.

The best preserved organic matter of marine origin was found in early to middle Albian at Sites 370 and 545 and also in late Albian to Vraconian in Site 545. Altered material of the same origin characterizes the early Cenomanian for the three sites (Fig. 16). Alteration increases from site 545 to Site 547 . Altered marine material also characterizes the Vraconian to late Albian period for Site 370 and Site 547. In the latter, several trends of increasing alteration are observed, with an increase in the OI corresponding to a decrease in both the $\mathrm{HI}$ and the organic carbon content. Intraformational conglomerates (pebbly claystone) at or close to the bottom of a trend as found at intervals $547 \mathrm{~A}-73-3,52 \mathrm{~cm}, 547 \mathrm{~A}-71-1$, $52 \mathrm{~cm}$, and $547 \mathrm{~A}-61-3,52 \mathrm{~cm}$ indicate a gravitational resedimentation. Since the bottom of a trend corresponds with pebbly claystones at 547A-73-3, $52 \mathrm{~cm}, 547 \mathrm{~A}-71-1$, $52 \mathrm{~cm}$, and $547 \mathrm{~A}-61-3,52 \mathrm{~cm}$, the beginning of a gravitational resedimentation cycle is suggested.

Altered marine material also occurs in the late Aptian slices of Site 545 . Several trends, beginning with deeply altered at the base of a slice and evolving toward progressively less altered marine organic matter at the top were observed from $545-53-3,98 \mathrm{~cm}$ to $545-52-5,120 \mathrm{~cm}$, and $545-51-1,46 \mathrm{~cm}$; from $545-50-6,56 \mathrm{~cm}$ to $545-50-2$, $57 \mathrm{~cm}$ to $545-49-6,23 \mathrm{~cm}$, and $545-49-3,120 \mathrm{~cm}$; from $545-49-2,20 \mathrm{~cm}$ to $545-48-5,38 \mathrm{~cm}$, and $545-48-1$, $52 \mathrm{~cm}$. Deeply altered organic matter at the base represents terrestrial input that rhythmically disturbed the natural sedimentation of marine organic matter. Altered marine material also characterizes most of the early Aptian at Site 370. 
A

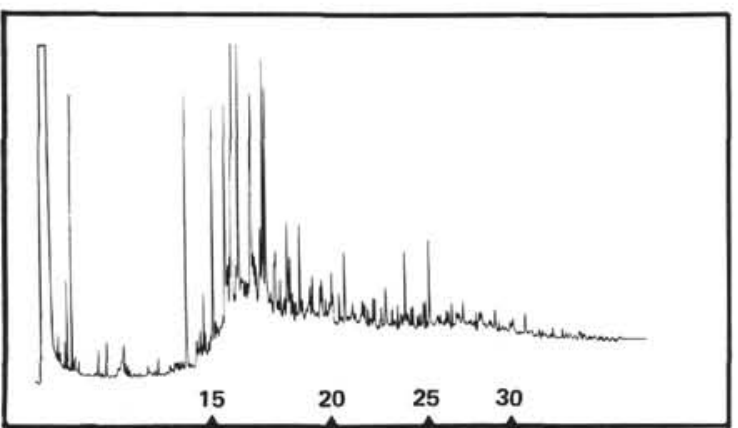

B

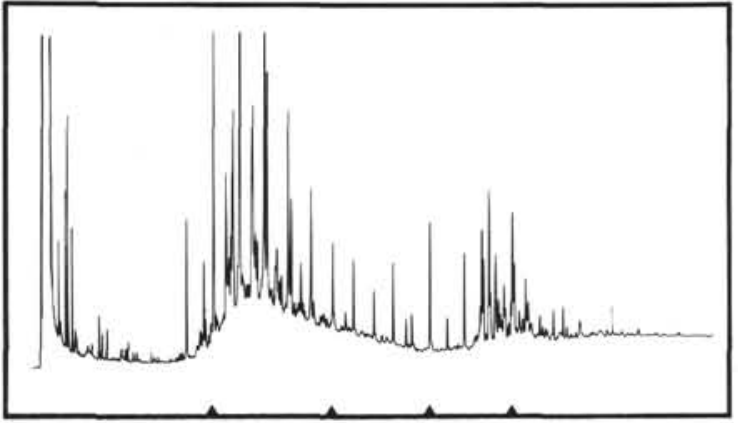

C

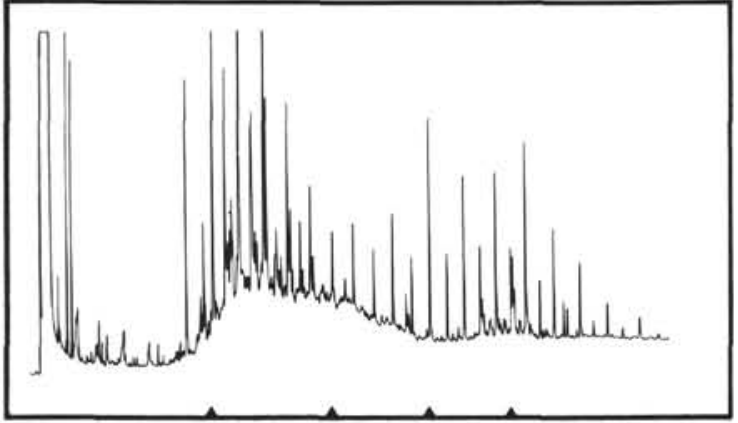

D

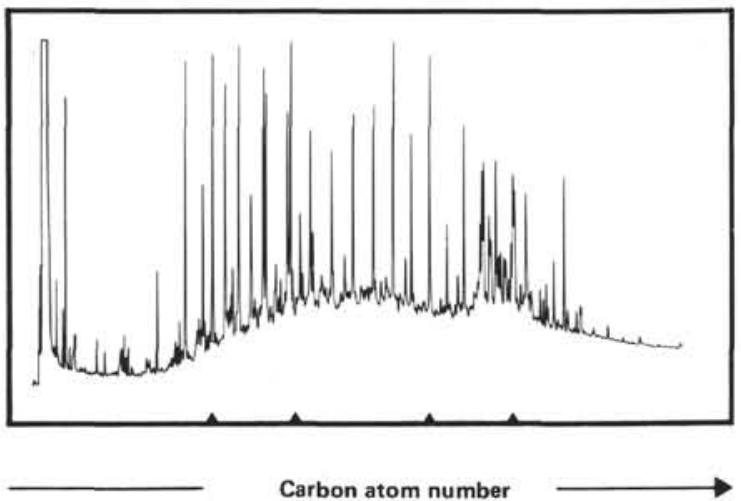

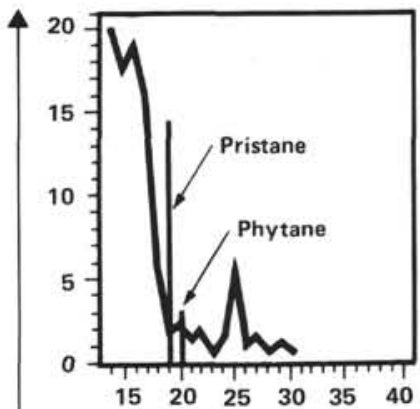
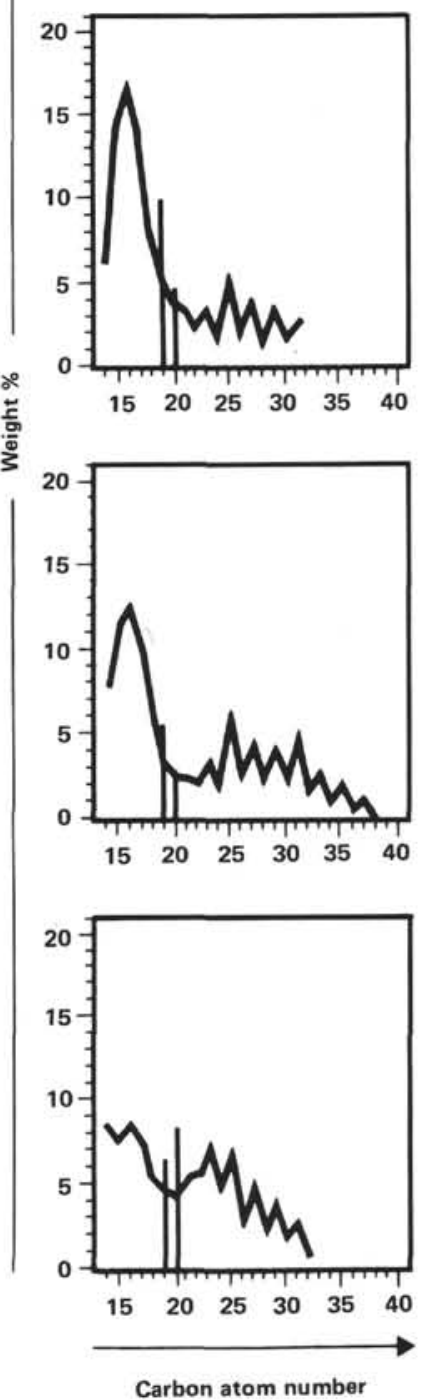

Figure 15. Chloroform extracts. Gas chromatography of saturated + unsaturated hydrocarbons. (A) Sample 547A-20-4, 55-56 to 547A-21-2, 85-86 cm; late Eocene. (B) Sample 545-40-3, 120-130 cm; late Albian. (C) Sample 545-55-5, 120-130 cm; late Aptian (Gargasian). (D) Sample 547A-73-3, 120-125 cm; Vraconian + late Albian.

\section{Vertical Distribution of Organic Matter and Environments of Deposition}

As shown before, variations of $\mathrm{HI}$ and $\mathrm{OI}$ indices reflect the conditions of preservation for immature marine organic matter when deposited. Thus, anoxic environments of deposition can be deduced given the wellpreserved marine organic matter detected at Sites 370,
545, and 547 (Fig. 16). HI and OI indices were studied for the entire Cretaceous interval.

During the late Aptian at Site 545, the mixing of altered marine organic matter with nonmarine altered organic matter was similar to the distribution observed within the late Barremian/early Aptian at Site 370. At Site 370 during the early to middle Albian, well-preserved organic matter of marine origin developed at the 


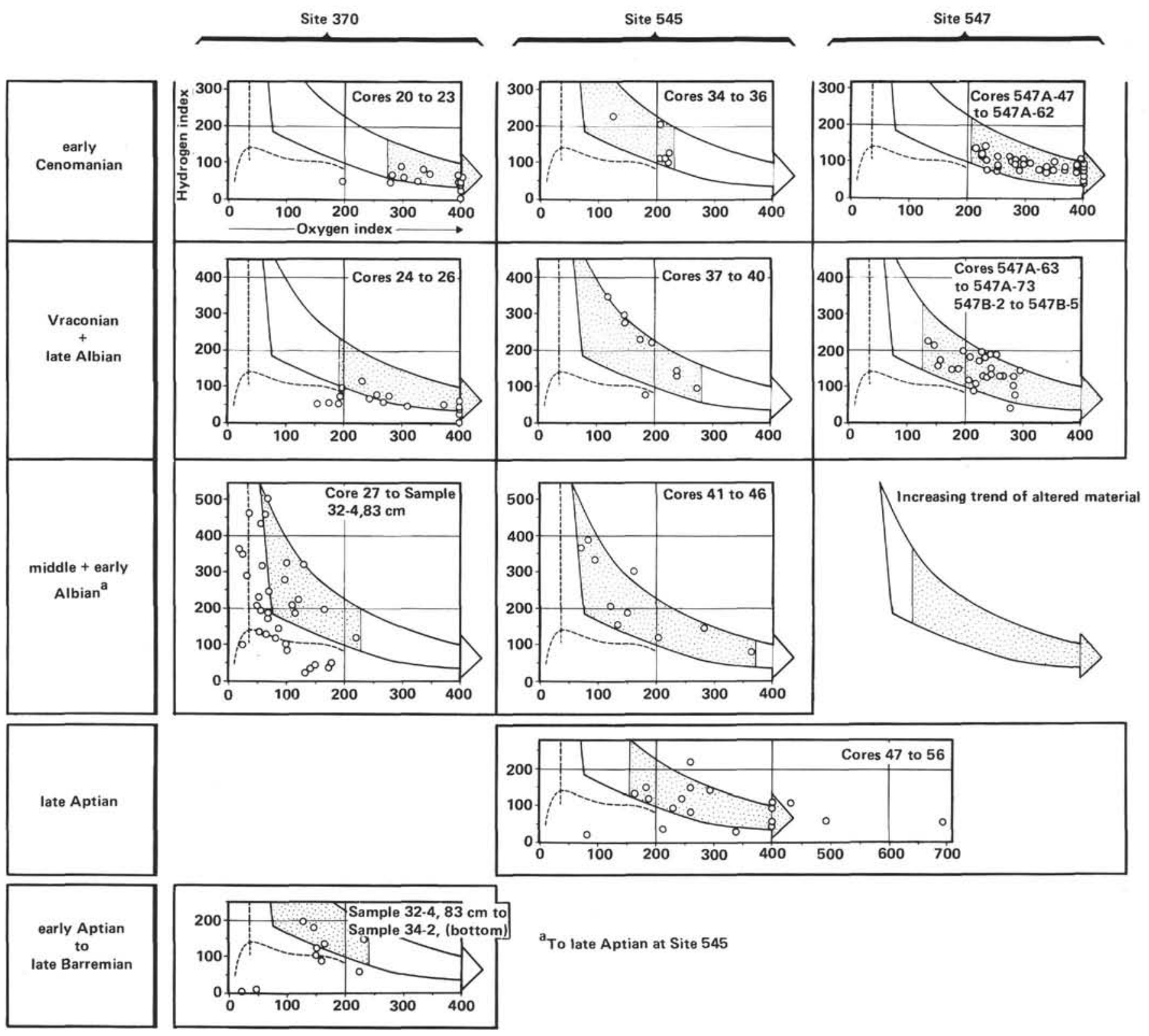

Figure 16. Vertical distribution and comparison of $\mathrm{HI}$ versus OI for Aptian to Cenomanian ages in Sites 370, 545 and 547.

upper and lower bounds of the interval in Cores 27 to 28 and Cores 30 to 32 , respectively. Reducing environments can be inferred even though nonmarine altered organic matter was present throughout the series. More landward at Site 545, altered marine organic matter characterizes the early Albian. Reducing environments and well-preserved marine organic matter appear later and extend from the middle to the late Albian. No continental organic material occurs.

Within the late Albian and the Vraconian at Site 370, altered marine organic matter prevails, interlayered with nonmarine organic matter. Reducing environments of deposition disappear later during the Vraconian at Site 545 . Here, altered marine organic matter is found in redeposited material of late Albian and Vraconian as in Site 547. Altered marine organic matter continues to be found within the early Cenomanian at the three sites, but alteration is less developed at Site 545 than at Sites 547 and 370 (Fig. 16). Table 4 sums up the distribution of organic matter and environments of deposition for the three sites within the Cretaceous interval.

\section{CONCLUSIONS}

Within the Eocene slumps of Unit III in Hole 547A, carbonate-rich and organic carbon rich contents correlate. Organic carbon rich material also occurs in Site 545 for the middle Albian part (Cores 41 to 43) of Subunit IIIA. A very low stage of maturation characterizes the organic matter throughout the middle Miocene to Pleistocene sections. The main zone of oil genesis (oil window) just reaches into the Jurassic section of Site 547 beyond $700 \mathrm{~m}$ depth. In that site, the anomalies of maturation observed for the samples of both EocenePaleocene Units III and IV and Jurassic Unit VII are 
Table 4. Vertical distribution of organic matter at Holes 370, 545, 547A, and 547B within Cretaceous sections.

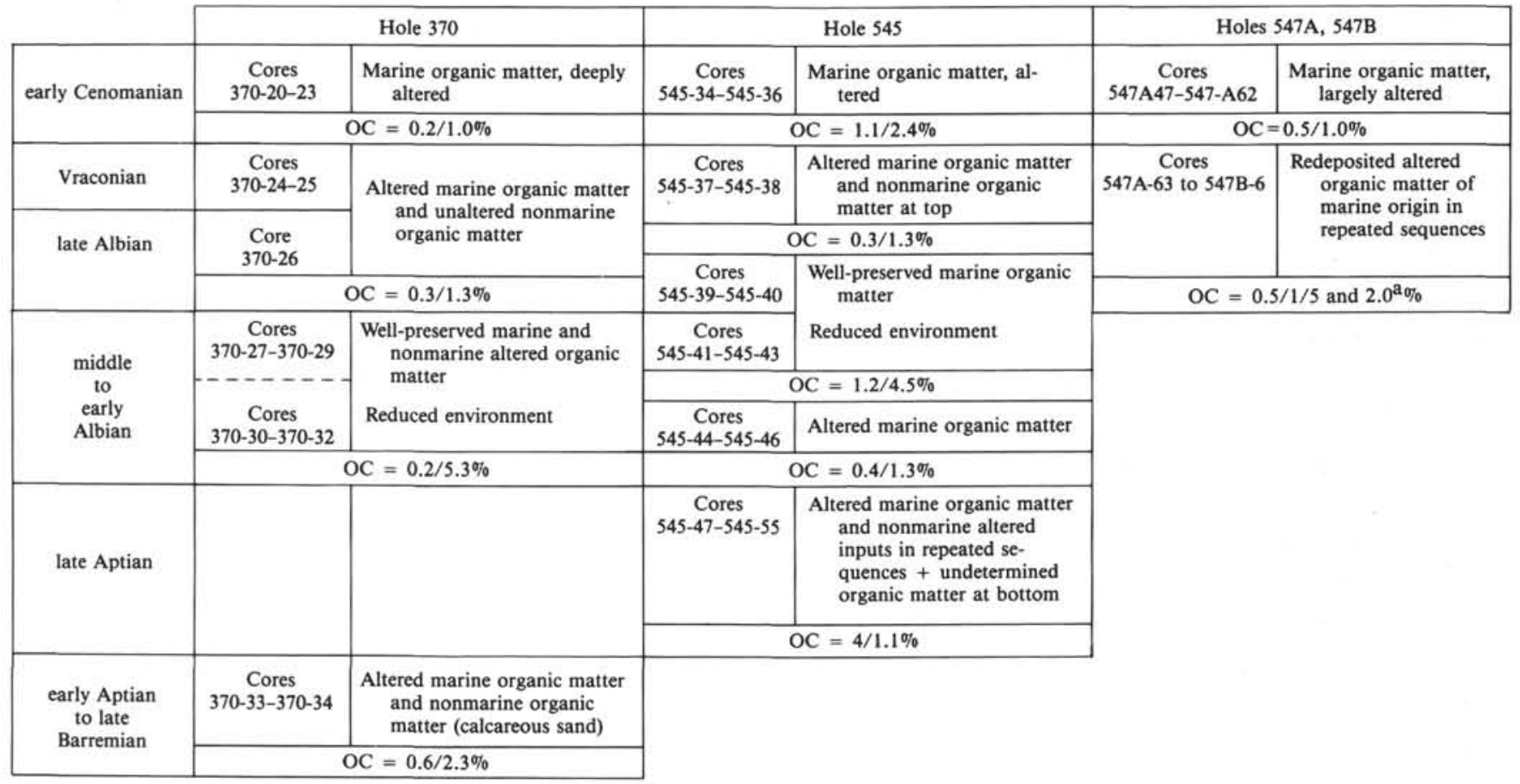

Note: $\mathrm{OC}=$ organic carbon

a On board analyses.

related to reworked and recycled material. Good petroleum potentials are found in the previously defined organic carbon rich intervals and also at the bottom of Cretaceous Unit V for Site 547.

Whereas various types of organic matter are present in the Jurassic samples (Units VI and VII) of Hole 547B, marine organic matter, variably altered, predominates throughout the Cretaceous series. The best preserved organic matter corresponds to the organic carbon rich layers and intervals defined above; if no redeposition occurred then the presence of organic matter implies reducing environments of deposition.

Along a transect from Sites 545 and 547 to 370 , oxygenated marine organic matter prevailed during Aptian time. The distribution in Site 370 and 545 is disturbed by inputs of nonmarine altered organic matter. Such altered material continued at Site 370 up to the Vraconian in spite of the presence of reducing environments of early to middle Albian age. However, reducing environments appear later at Site 545 during the middle Albian and extend to the late Albian. During the Vraconian and the Cenomanian periods, variably altered marine organic matter characterizes all the sites, including the sedimentary sequences that lie directly upon the Late Jurassic at Site 547.

Thus, away from the Mazagan escarpment, off the Agadir Canyon in the abyssal plain (Site 370), detrital inputs extend beyond the Albian and the reducing environments appear earlier in the Albian than at the bottom edge of the escarpment (Site 545). After the reducing period, marine organic matter is variably oxidized throughout the late Albian to Cenomanian periods.

\section{ACKNOWLEDGMENTS}

The authors are indebted to Dr. R. Cunningham and to Dr. Leslie B. Magoon III for reviewing the present paper.

\section{REFERENCES}

Cornford, C., 1979. Organic deposition at a continental rise: organic geochemical interpretation and synthesis at DSDP Site 397, Eastern North Atlantic. In von Rad, U., Ryan, W. B. F. et al., Init. Repts. DSDP, 47, Pt. 1: Washington (U.S. Govt. Printing Office), 503-510.

Deroo, G., Herbin, J. P., Roucaché, J., and Tissot, B., 1979. Organic geochemistry of some organic-rich shales from DSDP Site 397, Leg 47 A, Eastern North Atlantic. In von Rad, U., Ryan, W. B. F. et al., Init. Repts. DSDP , 47, Pt. 1: Washington (U.S. Govt. Printing Office), 523-529.

Deroo, G., Herbin, J. P., and Roucaché, J., 1983. Organic geochemistry of Cretaceous sediments from Site 511, Leg 71, Western South Atlantic. In Ludwig, W. J., Krasheninnikov, V. A., et al., Init. Repts. DSDP, 71: Washington (U.S. Govt. Printing Office).

Deroo, G., Herbin, J. P., and Huc, A. Y., in press. Organic geochemistry of Cretaceous black shales from DSDP Site 530, Leg 75, Eastern South Atlantic. In Hay, W. W., Sibuet, J. C., et al., Init. Repts. DSDP, 75: Washington (U.S. Govt. Printing Office).

Espitalié, J., and Deroo, G., in press. The development of Rock-Eval analysis. In Ikan, R., and Aizenshtat, Z. (Eds.), Organic Thermogeochemistry.

Espitalié, J., Laporte, J. L., Madec, M., Marquis, F., Leplat, P., Paulet, J., and Boutefeu, A., 1977. Méthode rapide de caractérisation des roches-mères, de leur potentiel pétrolier et de leur degré d'évolution. Rev. Inst. Fr. Pétrole, 32:23-42.

Espitalié, J., Marquis, F., and Barsony, I., in press. Geochemical logging. In Voorhees, K. J. (Ed.), Analytical Pyrolysis. 5th Int. Meeting on Analytical Pyrolysis, Vail, Colorado, Sept. 1982.

Graciansky, P. C. de, Brosse, E., Deroo, G., Herbin, J. P., Montadert, L., Müller, C., Schaaf, A., and Sigal, J., 1982. Les formations d'âge Crétacé de l'Atlantique Nord et leur matière organique: paléogéographie et milieux de dépôt. Rev. Inst. Fr. Pét., 37:275-336.

Huc, A. Y., Durand, B., and Monin, J. C., 1978. Humic compounds and kerogen in cores from Black Sea sediments, Leg 42-B, Holes 
379-A, B and 380-A. In Ross, D. A., Neprochnov, Y. P. et al., Init. Repts. DSDP, 42, Pt. 2: Washington (U.S. Govt. Printing Office), 737-748.

Tissot, B., Durand, B., Espitalié, J., and Combaz, A., 1974. Influence of the nature and diagenesis of organic matter in the formation of petroleum. Am. Assoc. Pet. Geol. Bull., 58:499-506.

Tissot, B., Deroo, G., and Hood, A., 1978. Geochemical study of the Uinta basin: formation of petroleum from the Green River Formation. Geochem. Cosmochim. Acta, 42:1469-1485.
Tissot, B., Deroo, G., and Herbin, J. P., 1979. Organic matter in Cretaceous sediments of the North Atlantic: contribution to sedimentology and paleogeography. In Talwani, M., Hay, W., Ryan, W. B. F. (Eds.), Deep drilling results in the Atlantic Ocean: continental margins and paleoenvironment, Am. Geophys. Un., Maurice Ewing Ser., 3:362-374.

Date of Initial Receipt: November 8, 1982

Date of Acceptance: August 4, 1983

APPENDIX

Sample Information, Carbon, and Pyrolysis Assay Data

Table 1. Site 544.

\begin{tabular}{|c|c|c|c|c|c|c|c|c|c|}
\hline $\begin{array}{l}\text { Core, section } \\
\text { (interval in } \mathrm{cm} \text { ) }\end{array}$ & $\begin{array}{l}\text { Depth } \\
\text { below } \\
\text { seafloor } \\
\text { (m) }\end{array}$ & $\begin{array}{c}\text { Geological } \\
\text { formation } \\
\text { or } \\
\text { Unit }\end{array}$ & $\begin{array}{l}\text { Mineral } \\
\text { carbon } \\
(w t . \%)\end{array}$ & $\begin{array}{l}\text { Organic } \\
\text { carbon } \\
\text { (wt. \%) }\end{array}$ & $\begin{array}{l}\text { Hydrogen } \\
\text { index } \\
\text { (mg hydro- } \\
\text { carbons/g } \\
\text { OC) }\end{array}$ & $\begin{array}{c}\text { Oxygen } \\
\text { index } \\
(\mathrm{mg} \mathrm{CO} 2 / \mathrm{g} \\
\mathrm{OC})\end{array}$ & $\begin{array}{l}\text { Petroleum } \\
\text { potential } \\
\text { (mg hydro- } \\
\text { carbons/g } \\
\text { rock) }\end{array}$ & $\begin{array}{l}\text { Pyrolysis } \\
\text { tempera- } \\
\text { ture } \\
\left({ }^{\circ} \mathrm{C}\right)\end{array}$ & $\begin{array}{l}\text { Production } \\
\text { index } \\
\text { (PI) }\end{array}$ \\
\hline \multicolumn{10}{|l|}{ Hole 544A } \\
\hline $1-5(75-76)$ & 6.75 & \multirow{16}{*}{ Unit I } & 9.4 & 0.12 & 225 & 1475 & 0.42 & 502 & 0.36 \\
\hline $2-1(100-102)$ & 8.00 & & 7.6 & 0.18 & 17 & 1000 & 0.11 & 355 & 0.80 \\
\hline $2-3(100-102)$ & 11.00 & & 6.5 & 0.15 & 347 & 1167 & 0.60 & 450 & 0.13 \\
\hline $2-5(100-102)$ & 14.00 & & 7.8 & 0.18 & 194 & 961 & 0.45 & 455 & 0.23 \\
\hline $3-1(65-68)$ & 17.15 & & 7.7 & 0.17 & 59 & 1000 & 0.21 & 392 & 0.55 \\
\hline $3-3(8-9)$ & 19.58 & & 8.1 & 0.21 & 95 & 852 & 0.32 & 448 & 0.37 \\
\hline $6-3(140-141)$ & 49.40 & & 8.7 & 0.09 & 0 & 1789 & 0.08 & & 1.00 \\
\hline $7-1(100-101)$ & 55.50 & & 7.9 & 0.18 & 67 & 878 & 0.24 & 403 & 0.50 \\
\hline $7-3(100-101)$ & 57.50 & & 8.4 & 0.14 & 121 & 929 & 0.26 & 453 & 0.35 \\
\hline $8-1(80-81)$ & 64.80 & & 12.0 & 0.11 & 73 & 1027 & 0.10 & 421 & 0.20 \\
\hline $8-3(80-81)$ & 67.80 & & 9.5 & 0.12 & 67 & 1025 & 0.11 & 380 & 0.30 \\
\hline $9-1$ (34-35) & 73.84 & & 9.6 & 0.13 & 92 & 946 & 0.17 & 415 & 0.31 \\
\hline $9-3(34-35)$ & 76.84 & & 8.5 & 0.15 & 100 & 933 & 0.21 & 402 & 0.30 \\
\hline $10-1(130-131)$ & 84.30 & & 9.1 & 0.09 & 78 & 1355 & 0.07 & 383 & 0.00 \\
\hline $10-3(130-131)$ & 87.30 & & 8.4 & 0.11 & 64 & 1264 & 0.10 & 335 & 0.30 \\
\hline $10-5(131-131)$ & 90.30 & & 8.0 & 0.10 & 70 & 1330 & 0.08 & 363 & 0.12 \\
\hline $20-2(135-145)$ & 159.85 & Unit IVA & 1.8 & 0.13 & 554 & 331 & 0.84 & 517 & 0.14 \\
\hline $6-3(75-76)$ & 23.75 & \multirow{7}{*}{ Unit I } & 8.5 & 0.14 & 71 & 1179 & 0.20 & 417 & 0.50 \\
\hline $7-2(77-78)$ & 26.67 & & 7.9 & 0.10 & 60 & 1580 & 0.11 & 360 & 0.50 \\
\hline $8-2(20-21)$ & 29.10 & & 8.7 & 0.10 & 80 & 1460 & 0.15 & 400 & 0.50 \\
\hline $9-2(72-73)$ & 33.12 & & 9.0 & 0.09 & 67 & 1578 & 0.15 & 410 & 0.64 \\
\hline $10-2(56-57)$ & 35.76 & & 8.9 & 0.11 & 73 & 1300 & 0.17 & 461 & 0.56 \\
\hline $11-1(40-41)$ & 36.80 & & 8.9 & 0.13 & 17 & 1031 & 0.12 & 339 & 0.58 \\
\hline $12-1(41-47)$ & 37.81 & & 9.0 & 0.19 & 42 & 710 & 0.18 & 364 & 0.56 \\
\hline
\end{tabular}


Table 2. Hole 545 .

\begin{tabular}{|c|c|c|c|c|c|c|c|c|c|}
\hline $\begin{array}{l}\text { Core, section } \\
\text { (interval in cm) }\end{array}$ & $\begin{array}{l}\text { Depth } \\
\text { below } \\
\text { seafloor } \\
\text { (m) }\end{array}$ & $\begin{array}{c}\text { Geological } \\
\text { formation } \\
\text { or } \\
\text { Unit }\end{array}$ & $\begin{array}{l}\text { Mineral } \\
\text { carbon } \\
\text { (wt. \%) }\end{array}$ & $\begin{array}{l}\text { Organic } \\
\text { carbon } \\
(w t . \%)\end{array}$ & $\begin{array}{l}\text { Hydrogen } \\
\text { index } \\
\text { (mg hydro- } \\
\text { carbons } / \mathrm{g} \\
\text { OC) }\end{array}$ & $\begin{array}{c}\text { Oxygen } \\
\text { index } \\
\left(\mathrm{mg} \mathrm{CO}_{2} / \mathrm{g}\right. \\
\mathrm{OC})\end{array}$ & $\begin{array}{c}\text { Petroleum } \\
\text { potential } \\
\text { (mg hydro- } \\
\text { carbons/g } \\
\text { rock) }\end{array}$ & $\begin{array}{c}\text { Pyrolysis } \\
\text { tempera- } \\
\text { ture } \\
\left({ }^{\circ} \mathrm{C}\right)\end{array}$ & $\begin{array}{l}\text { Production } \\
\text { index } \\
\text { (PI) }\end{array}$ \\
\hline $1-1(90-91)$ & 0.90 & \multirow{7}{*}{ Unit IA } & 7.2 & 0.28 & 75 & 1064 & 0.41 & 401 & 0.50 \\
\hline $2-2(90-91)$ & 10.90 & & 5.9 & 0.47 & 106 & 596 & 0.84 & 410 & 0.40 \\
\hline $3-1(90-91)$ & 18.90 & & 4.4 & 0.46 & 33 & 565 & 0.63 & 392 & 0.40 \\
\hline $3-3(90-91)$ & 21.90 & & 3.1 & 0.34 & 62 & 603 & 0.39 & 437 & 0.47 \\
\hline $3-5(90-91)$ & 24.21 & & 7.0 & 0.40 & 93 & 555 & 0.59 & 414 & 0.38 \\
\hline $4-1(90-91)$ & 28.40 & & 7.2 & 0.41 & 102 & 524 & 0.65 & 417 & 0.36 \\
\hline $8-3(60-61)$ & 69.10 & & 7.1 & 0.36 & 38 & 478 & 0.41 & 403 & 0.50 \\
\hline $10-2(70-71)$ & 86.70 & \multirow{7}{*}{ Unit IB } & 8.1 & 0.19 & 105 & 826 & 0.34 & 402 & 0.41 \\
\hline $11-3(45-46)$ & 97.45 & & 9.3 & 0.12 & 75 & 1125 & 0.18 & 437 & 0.50 \\
\hline $12-4(50-51)$ & 108.50 & & 9.0 & 0.13 & 69 & 931 & 0.17 & 397 & 0.50 \\
\hline $13-2(50-51)$ & 115.00 & & 8.8 & 0.15 & 47 & 867 & 0.14 & 404 & 0.50 \\
\hline $14-2(50-51)$ & 124.50 & & 8.6 & 0.12 & 75 & 1383 & 0.17 & 440 & 0.50 \\
\hline $19-4(34-35)$ & 174.34 & & 7.7 & 0.19 & 68 & 747 & 0.24 & 395 & 0.46 \\
\hline $20-1(58-59)$ & 179.58 & & -9.5 & 0.19 & 89 & 668 & 0.26 & 412 & 0.35 \\
\hline $21-1(50-51)$ & 189.00 & \multirow{10}{*}{ Unit II } & 9.5 & 0.12 & 83 & 1067 & 0.18 & 402 & 0.44 \\
\hline $22-1(50-51)$ & 198.50 & & 9.3 & 0.12 & 67 & 1125 & 0.16 & 402 & 0.50 \\
\hline $22-1(60-61)$ & 198.60 & & 8.9 & 0.13 & 62 & 908 & 0.17 & 403 & 0.56 \\
\hline $23-1(5-6)$ & 212.05 & & 8.7 & 0.14 & 71 & 1057 & 0.21 & 425 & 0.55 \\
\hline $24-1(40-41)$ & 217.40 & & 7.7 & 0.56 & 104 & 318 & 0.73 & 421 & 0.21 \\
\hline $24-4(5-6)$ & 221.55 & & 7.7 & 0.14 & 50 & 1086 & 0.15 & 407 & 0.57 \\
\hline $25-3(20-21)$ & 229.70 & & 8.5 & 0.17 & 47 & 794 & 0.17 & 404 & 0.56 \\
\hline $26-1$ (93-94) & 236.93 & & 5.3 & 0.61 & 136 & 330 & 1.10 & 418 & 0.25 \\
\hline $26-1(120-130)$ & 237.20 & & 6.7 & 0.45 & 78 & 473 & 0.48 & 413 & 0.27 \\
\hline $27-1(94-95)$ & 246.44 & & 4.4 & 0.77 & 136 & 262 & 1.37 & 420 & 0.24 \\
\hline $28-1(63-64)$ & 255.63 & \multirow{28}{*}{ Unit IIIA } & 2.4 & 0.73 & 58 & 329 & 0.58 & 417 & 0.28 \\
\hline $29-1(23-24)$ & 264.73 & & 2.3 & 0.55 & 51 & 453 & 0.41 & 411 & 0.32 \\
\hline $29-1(135-145)$ & 265.85 & & 2.9 & 0.88 & 142 & 314 & 1.44 & 424 & 0.13 \\
\hline $30-1(3-4)$ & 274.03 & & 2.7 & 1.05 & 72 & 356 & 0.99 & 420 & 0.23 \\
\hline $31-1(9-10)$ & 283.59 & & 1.8 & 0.72 & 161 & 432 & 1.48 & 422 & 0.22 \\
\hline $32-1(38-39)$ & 293.38 & & 3.2 & 1.21 & 154 & 250 & 2.25 & 425 & 0.17 \\
\hline $33-1(20-21)$ & 302.70 & & 3.4 & 1.03 & 115 & 239 & 1.46 & 411 & 0.18 \\
\hline $34-1(84-85)$ & 313.34 & & 2.3 & 2.36 & 229 & 127 & 5.86 & 423 & 0.08 \\
\hline $34-1(117-119)$ & 313.67 & & 4.1 & 1.20 & 109 & 220 & 1.54 & 423 & 0.15 \\
\hline $34-2(50-51)$ & 314.50 & & 4.0 & 1.18 & 130 & 223 & 1.77 & 426 & 0.13 \\
\hline $34-2(120-130)$ & 315.20 & & 3.9 & 1.57 & 204 & 208 & 3.53 & 424 & 0.09 \\
\hline $35-1(20-21)$ & 322.20 & & 4.0 & 1.22 & 115 & 216 & 1.64 & 423 & 0.15 \\
\hline $36-1$ (95-96) & 332.45 & & 4.3 & 1.10 & 115 & 209 & 1.46 & 422 & 0.14 \\
\hline $37-2(42-43)$ & 342.92 & & 3.1 & 1.27 & 75 & 184 & 1.14 & 418 & 0.17 \\
\hline $37-2(135-145)$ & 343.85 & & 4.1 & 0.94 & 96 & 272 & 1.13 & 417 & 0.20 \\
\hline $38-2(100-101)$ & 353.00 & & 8.4 & 1.88 & 345 & 119 & 6.95 & 424 & 0.07 \\
\hline $38-3(100-101)$ & 354.50 & & 6.4 & 1.01 & 143 & 239 & 1.62 & 424 & 0.11 \\
\hline $39-2(99-100)$ & 362.49 & & 3.6 & 1.22 & 138 & 239 & 1.98 & 423 & 0.15 \\
\hline $39-4(99-100)$ & 365.49 & & 6.2 & 1.94 & 294 & 148 & 6.13 & 422 & 0.07 \\
\hline $40-2(35-36)$ & 371.05 & & 6.4 & 1.33 & 227 & 175 & 3.30 & 425 & 0.08 \\
\hline $40-3(120-130)$ & 373.70 & & 4.9 & 1.39 & 219 & 195 & 3.48 & 423 & 0.13 \\
\hline $40-5(57-58)$ & 376.07 & & 5.5 & 1.58 & 273 & 149 & 4.74 & 424 & 0.09 \\
\hline $41-1(41-42)$ & 379.41 & & 4.6 & 3.76 & 387 & 83 & 15.23 & 423 & 0.04 \\
\hline $41-4(30-31)$ & 383.80 & & 5.1 & 2.38 & 331 & 95 & 8.36 & 422 & 0.06 \\
\hline $42-2(20-22)$ & 390.20 & & 3.3 & 4.46 & 363 & 71 & 17.12 & 420 & 0.06 \\
\hline $43-4(135-145)$ & 403.85 & & 4.9 & 1.56 & 299 & 163 & 5.08 & 423 & 0.08 \\
\hline $43-6,94-95$ & 460.44 & & 5.0 & 1.65 & 202 & 122 & 3.62 & 423 & 0.08 \\
\hline $44-1(0-1)$ & 407.50 & & -7.9 & 0.39 & 77 & 364 & 0.36 & 416 & 0.17 \\
\hline $45-4$ (94-95) & 422.44 & \multirow{19}{*}{ Unit IIIB } & 3.9 & 1.30 & 152 & 134 & 2.19 & 425 & 0.10 \\
\hline $46-2(62-63)$ & 428.62 & & 6.0 & 0.72 & 117 & 205 & 0.88 & 427 & 0.05 \\
\hline $46-4(62-63)$ & 431.62 & & 5.3 & 1.30 & 184 & 151 & 2.61 & 425 & 0.08 \\
\hline $46-4(120-130)$ & 432.20 & & 5.4 & 0.80 & 141 & 283 & 1.31 & 420 & 0.14 \\
\hline $47-2(95-96)$ & 438.45 & & 5.9 & 0.99 & 134 & 163 & 1.53 & 421 & 0.13 \\
\hline $47-6(71-72)$ & 444.21 & & 7.1 & 0.63 & 122 & 187 & 0.85 & 424 & 0.10 \\
\hline $48-1(52-53)$ & 446.02 & & 7.0 & 0.67 & 151 & 182 & 1.12 & 424 & 0.10 \\
\hline $48-5(38-39)$ & 451.88 & & 5.3 & 0.70 & 143 & 293 & 1.18 & 418 & 0.15 \\
\hline $49-2(23-24)$ & 456.73 & & 7.1 & 0.48 & 98 & 229 & 0.55 & 416 & 0.15 \\
\hline $49-3(120-130)$ & 459.20 & & 6.6 & 0.51 & 151 & 259 & 0.84 & 420 & 0.08 \\
\hline $49-6(20-21)$ & 462.70 & & 8.2 & 0.43 & 123 & 244 & 0.60 & 419 & 0.12 \\
\hline $50-2(57-58)$ & 466.57 & & 5.1 & 0.53 & 87 & 260 & 0.53 & 393 & 0.13 \\
\hline $50-6(56-57)$ & 472.56 & & 6.0 & 0.57 & 39 & 212 & 0.30 & 395 & 0.27 \\
\hline $51-1(46-47)$ & 474.46 & & 6.1 & 0.37 & 105 & 432 & 0.49 & 408 & 0.21 \\
\hline $52-5(25-26)$ & 489.75 & & 6.6 & 0.38 & 403 & 360 & 1.73 & 421 & 0.12 \\
\hline $52-5(120-130)$ & 490.70 & & 6.5 & 0.40 & 60 & 488 & 0.30 & 410 & 0.20 \\
\hline $53-3(98-100)$ & 496.98 & & 5.4 & 0.60 & 32 & 338 & 0.25 & 447 & 0.25 \\
\hline $54-4(130-132)$ & 508.30 & & 6.8 & 0.40 & 53 & 688 & 0.31 & 391 & 0.33 \\
\hline $55-5(120-130)$ & 519.20 & & -7.5 & 0.89 & 221 & 258 & 2.16 & 426 & 0.09 \\
\hline $55, \mathrm{CC}(16-17)$ & 519.66 & \multirow{3}{*}{ Unit IIIC } & 5.6 & 1.12 & 22 & 81 & 0.32 & 377 & 0.22 \\
\hline $56-4(59-60)$ & 526.59 & & 6.5 & 0.24 & 113 & 554 & 0.33 & 414 & 0.19 \\
\hline $56-6(58-59)$ & 529.58 & & 5.7 & 0.09 & 378 & 3155 & 0.52 & 366 & 0.35 \\
\hline
\end{tabular}


Table 3. Hole 546.

\begin{tabular}{|c|c|c|c|c|c|c|c|c|c|}
\hline $\begin{array}{l}\text { Core, section } \\
\text { (interval in } \mathrm{cm} \text { ) }\end{array}$ & $\begin{array}{l}\text { Depth } \\
\text { below } \\
\text { seafloor } \\
\text { (m) }\end{array}$ & $\begin{array}{c}\text { Geological } \\
\text { formation } \\
\text { or } \\
\text { Unit }\end{array}$ & $\begin{array}{l}\text { Mineral } \\
\text { carbon } \\
(w t . \%)\end{array}$ & $\begin{array}{l}\text { Organic } \\
\text { carbon } \\
\text { (wt.\%) }\end{array}$ & $\begin{array}{c}\text { Hydrogen } \\
\text { index } \\
\text { (mg hydro- } \\
\text { carbons/g } \\
\text { OC) }\end{array}$ & $\begin{array}{c}\text { Oxygen } \\
\text { index } \\
\left(\mathrm{mg} \mathrm{CO} \mathrm{CO}_{2} / \mathrm{g}\right. \\
\mathrm{OC})\end{array}$ & $\begin{array}{c}\text { Petroleum } \\
\text { potential } \\
\text { (mg hydro- } \\
\text { carbons } / \mathrm{g} \\
\text { rock) }\end{array}$ & $\begin{array}{c}\text { Pyrolysis } \\
\text { tempera- } \\
\text { ture } \\
\left({ }^{\circ} \mathrm{C}\right)\end{array}$ & $\begin{array}{l}\text { Production } \\
\text { index } \\
\text { (PI) }\end{array}$ \\
\hline $1-1(100-101)$ & 1.00 & & 5.1 & 0.32 & 75 & 809 & 0.39 & 417 & 0.39 \\
\hline $2-1(25-26)$ & 2.25 & & 7.2 & 0.26 & 54 & 754 & 0.24 & 439 & 0.42 \\
\hline $2-3(25-26)$ & 5.25 & & 5.4 & 0.28 & 57 & 800 & 0.24 & 453 & 0.33 \\
\hline $3-1(79-80)$ & 12.29 & & 9.5 & 0.17 & 118 & 1018 & 0.31 & 433 & 0.37 \\
\hline $3-3(79-80)$ & 15.29 & & 5.6 & 0.18 & 83 & 939 & 0.22 & 439 & 0.32 \\
\hline $4-1(125-126)$ & 22.25 & & 6.7 & 0.19 & 95 & 1116 & 0.29 & 407 & 0.39 \\
\hline $4-3(125-126)$ & 25.25 & & 6.4 & 0.19 & 99 & 974 & 0.27 & 414 & 0.38 \\
\hline $6-1(145-146)$ & 41.45 & & 6.8 & 0.20 & 85 & 760 & 0.28 & 444 & 0.39 \\
\hline $6-3(30-32)$ & 43.30 & & 4.9 & 0.23 & 65 & 878 & 0.24 & 445 & 0.37 \\
\hline $6-4(34-36)$ & 44.84 & & 6.7 & 0.19 & 68 & 979 & 0.21 & 452 & 0.40 \\
\hline $7-1(80-83)$ & 50.30 & & 6.5 & 0.18 & 78 & 900 & 0.23 & 447 & 0.41 \\
\hline $7-3(80-83)$ & 53.30 & & 5.8 & 0.16 & 69 & 988 & 0.20 & 437 & 0.45 \\
\hline $7-5(80-83)$ & 56.30 & & 6.4 & 0.17 & 59 & 853 & 0.17 & 432 & 0.44 \\
\hline $8-2(20-22)$ & 60.70 & & 7.2 & 0.17 & 76 & 847 & 0.23 & 445 & 0.45 \\
\hline $8-4(20-22)$ & 63.70 & & 7.6 & 0.15 & 53 & 980 & 0.17 & 381 & 0.56 \\
\hline $8-6(20-22)$ & 66.70 & Unit 1 & 7.8 & 0.12 & 67 & 1125 & 0.16 & 387 & 0.50 \\
\hline $9-1(20-22)$ & 68.70 & & 7.7 & 0.15 & 53 & 947 & 0.19 & 457 & 0.61 \\
\hline $9-3(20-22)$ & 71.70 & & 7.9 & 0.13 & 62 & 1138 & 0.17 & 352 & 0.56 \\
\hline $9-5(20-22)$ & 74.70 & & 7.7 & 0.13 & 69 & 1038 & 0.16 & 383 & 0.44 \\
\hline $10-1(20-22)$ & 78.20 & & 7.6 & 0.15 & 40 & 940 & 0.13 & 380 & 0.58 \\
\hline $10-3(20-22)$ & 81.20 & & 7.6 & 0.14 & 50 & 1000 & 0.16 & 403 & 0.56 \\
\hline $10-5(20-22)$ & 84.20 & & 7.6 & 0.11 & 0 & 218 & 0.01 & 327 & 0.00 \\
\hline $11-1(20-22)$ & 87.70 & & 8.1 & 0.11 & 100 & 1391 & 0.20 & 368 & 0.45 \\
\hline $11-3(20-22)$ & 90.70 & & 8.6 & 0.12 & 30 & 1167 & 0.13 & 372 & 0.58 \\
\hline $12-2(102-103)$ & 99.52 & & 8.4 & 0.11 & 45 & 1327 & 0.10 & 329 & 0.50 \\
\hline $12-4(102-103)$ & 102.52 & & 8.5 & 0.13 & 62 & 1015 & 0.12 & 396 & 0.33 \\
\hline $13-1(100-101)$ & 107.50 & & 8.6 & 0.12 & 83 & 1117 & 0.19 & 436 & 0.47 \\
\hline $13-3(100-101)$ & 110.50 & & 9.2 & 0.09 & 144 & 1389 & 0.16 & 541 & 0.19 \\
\hline $14-1(100-101)$ & 117.00 & & 7.7 & 0.09 & 244 & 1478 & 0.26 & 528 & 0.15 \\
\hline $14-3(100-101)$ & 120.00 & & 8.7 & 0.09 & 211 & 1422 & 0.24 & 517 & 0.21 \\
\hline $15-1(47-48)$ & 125.97 & & 7.3 & 0.25 & 216 & 716 & 0.68 & 416 & 0.21 \\
\hline $17-1(76-77)$ & 146.26 & & 9.1 & 0.07 & 157 & 1200 & 0.13 & 514 & 0.17 \\
\hline $17-2(43-44)$ & 146.43 & & 1.8 & 0.20 & 420 & 235 & 0.88 & 544 & 0.05 \\
\hline $17-2(52-53)$ & 146.52 & Unit II & 4.0 & 0.10 & 240 & 470 & 0.27 & 488 & 0.12 \\
\hline $17-3(22-23)$ & 147.72 & & 6.9 & 0.69 & 113 & 239 & 0.82 & 427 & 0.05 \\
\hline $17-4(22-23)$ & 149.22 & & 1.6 & 0.41 & 76 & 41 & 0.35 & 496 & 0.12 \\
\hline $18-1(0-10)$ & 154.00 & & 1.7 & 0.27 & 337 & 52 & 0.93 & 550 & 0.02 \\
\hline
\end{tabular}


Table 4. Site 547.

\begin{tabular}{|c|c|c|c|c|c|c|c|c|c|}
\hline $\begin{array}{l}\text { Core, section } \\
\text { (interval in } \mathrm{cm} \text { ) }\end{array}$ & $\begin{array}{c}\text { Depth } \\
\text { below } \\
\text { seafloor } \\
\text { (m) }\end{array}$ & $\begin{array}{c}\text { Geological } \\
\text { formation } \\
\text { or } \\
\text { Unit }\end{array}$ & $\begin{array}{l}\text { Mineral } \\
\text { carbon } \\
\text { (wt.\%) }\end{array}$ & $\begin{array}{l}\text { Organic } \\
\text { carbon } \\
\text { (wt.\%) }\end{array}$ & $\begin{array}{l}\text { Hydrogen } \\
\text { index } \\
\text { (mg hydro- } \\
\text { carbons } / 8 \\
\text { OC) }\end{array}$ & $\begin{array}{l}\begin{array}{c}\text { Oxygen } \\
\text { index } \\
(\mathrm{mg} \mathrm{CO})_{2} / \mathrm{g}\end{array} \\
\mathrm{OC})\end{array}$ & $\begin{array}{c}\text { Petroleum } \\
\text { potential } \\
\text { (mg hydro- } \\
\text { carbons } / \mathrm{g} \\
\text { rock) }\end{array}$ & $\begin{array}{c}\text { Pyrolysis } \\
\text { tempera- } \\
\text { ture } \\
\left({ }^{\circ} \mathrm{C}\right)\end{array}$ & $\begin{array}{l}\text { Production } \\
\text { index } \\
\text { (PI) }\end{array}$ \\
\hline Hole 547 & & & & & & & & & \\
\hline $\begin{array}{l}1-2(84-85) \\
16-2(30-31)\end{array}$ & $\begin{array}{r}2.34 \\
214.30\end{array}$ & Unit 1 & $\begin{array}{l}6.4 \\
6.0\end{array}$ & $\begin{array}{l}0.41 \\
0.19\end{array}$ & $\begin{array}{l}61 \\
63\end{array}$ & $\begin{array}{r}771 \\
1005\end{array}$ & $\begin{array}{l}0.43 \\
0.20\end{array}$ & $\begin{array}{l}393 \\
425\end{array}$ & $\begin{array}{l}0.43 \\
0.40\end{array}$ \\
\hline Hole 547A & & & & & & & & & \\
\hline $\begin{array}{l}1-4(89-90) \\
2-2(86-87) \\
3-1(32-33) \\
4-1(32-33) \\
5-3(27-28) \\
6-1(50-51) \\
7-1(52-53)\end{array}$ & $\begin{array}{r}56.39 \\
81.86 \\
89.32 \\
98.82 \\
111.27 \\
118.00 \\
127.52\end{array}$ & Unit I & $\begin{array}{l}6.6 \\
7.1 \\
7.2 \\
9.2 \\
8.4 \\
9.1 \\
9.2\end{array}$ & $\begin{array}{l}0.25 \\
0.23 \\
0.30 \\
0.10 \\
0.10 \\
0.22 \\
0.10\end{array}$ & $\begin{array}{l}44 \\
48 \\
60 \\
50 \\
50 \\
32 \\
30\end{array}$ & $\begin{array}{r}832 \\
930 \\
733 \\
733 \\
2000 \\
2130 \\
723 \\
1880\end{array}$ & $\begin{array}{l}0.22 \\
0.19 \\
0.29 \\
0.09 \\
0.10 \\
0.14 \\
0.06\end{array}$ & $\begin{array}{l}394 \\
437 \\
388 \\
416 \\
317 \\
461 \\
322\end{array}$ & $\begin{array}{l}0.50 \\
0.44 \\
0.39 \\
0.50 \\
0.50 \\
0.50 \\
0.50\end{array}$ \\
\hline $8-4(34-35)$ & 141.34 & & 8.4 & 0.17 & 53 & 1118 & 0.16 & 391 & 0.44 \\
\hline $8-5(34-35)$ & 142.84 & & 8.6 & 0.27 & 37 & 670 & 0.15 & 419 & 0.36 \\
\hline $9-1(71-72)$ & 146.71 & & 9.4 & 0.10 & 40 & 1630 & 0.08 & 344 & 0.50 \\
\hline $10-1(71-72)$ & 156.21 & & 9.2 & 0.50 & 92 & 256 & 0.57 & 405 & 0.20 \\
\hline $11-1(90-91)$ & 165.90 & & 7.8 & 0.27 & 104 & 633 & 0.39 & 384 & 0.29 \\
\hline $11-3(90-91)$ & 168.90 & & 8.8 & 0.11 & 55 & 1082 & 0.12 & 434 & 0.50 \\
\hline $12-1(60-61)$ & 175.10 & Unit IIA & 8.8 & 0.16 & 56 & 606 & 0.16 & 477 & 0.44 \\
\hline $12-3(60-61)$ & 178.10 & & 9.4 & 0.11 & 0 & 809 & 0.06 & & 1.00 \\
\hline $13-1(53-54)$ & 184.53 & & 9.2 & 0.11 & 236 & 1000 & 0.33 & 500 & 0.22 \\
\hline $14-2(80-81)$ & 195.80 & & 8.8 & 0.12 & 142 & 992 & 0.28 & 521 & 0.39 \\
\hline $14-4(80-81)$ & 198.80 & & 8.0 & 0.40 & 133 & 420 & 0.72 & 410 & 0.26 \\
\hline $15-1(35-36)$ & 203.35 & & 7.6 & 0.31 & 116 & 594 & 0.49 & 409 & 0.27 \\
\hline $17-2(10-11)$ & 223.60 & Unit IIB & 5.0 & 0.23 & 157 & 913 & 0.48 & 412 & 0.25 \\
\hline $19-1(41-43)$ & 241.41 & & 4.8 & 2.48 & 258 & 108 & 6.91 & 424 & 0.07 \\
\hline $19-1(49-51)$ & 241.49 & & 4.0 & 0.48 & 50 & 275 & 0.32 & 398 & 0.25 \\
\hline $20-1(55-56)$ & 251.05 & & 8.3 & 2.63 & 433 & 117 & 12.32 & 422 & 0.08 \\
\hline $20-4(55-56)$ & 255.55 & Unit III & 7.6 & 3.11 & 471 & III & 15.81 & 419 & 0.07 \\
\hline $21-2(85-86)$ & 262.35 & & 7.9 & 2.28 & 435 & 126 & 10.72 & 421 & 0.07 \\
\hline $21-4(85-86)$ & 265.35 & & 2.3 & 0.62 & 106 & 274 & 0.88 & 419 & 0.25 \\
\hline $21-6(85-86)$ & 268.35 & & 7.9 & 0.66 & 227 & 304 & 1.73 & 419 & 0.13 \\
\hline $22-2(85-86)$ & 271.85 & & 8.5 & 0.40 & 250 & 525 & 1.20 & 421 & 0.17 \\
\hline $23-3$ (79-80) & 282.79 & & 7.7 & 0.18 & 205 & 1428 & 0.57 & 449 & 0.36 \\
\hline $24-1(122-123)$ & 289.72 & & 7.8 & 0.18 & 167 & 1061 & 0.44 & 462 & 0.32 \\
\hline $25-4(16-17)$ & 302.66 & & 9.4 & 0.25 & 120 & 264 & 0.40 & 409 & 0.25 \\
\hline $26-1(44-45)$ & 307.94 & Unit IVA & 5.8 & 0.42 & 129 & 614 & 0.67 & 420 & 0.20 \\
\hline $27-1(103-104)$ & 318.03 & & 4.9 & 0.44 & 123 & sil & 0.69 & 421 & 0.22 \\
\hline $28-2(87-88)$ & 328.87 & & 6.7 & 0.25 & 152 & 696 & 0.46 & 423 & 0.17 \\
\hline $30-1(69-71)$ & 346.19 & & 7.8 & 0.19 & 68 & 679 & 0.17 & 441 & 0.25 \\
\hline $32-1(85-86)$ & 365.35 & & -3.1 & 0.14 & 286 & 936 & 0.50 & 450 & 0.20 \\
\hline $32-4(50-51)$ & 369.50 & & 2.5 & 0.24 & 146 & 842 & 0.50 & 428 & 0.30 \\
\hline $33-1(63-64)$ & 374.63 & & 7.8 & 0.32 & 109 & 478 & 0.42 & 424 & 0.17 \\
\hline $33-3(63-64)$ & 377.63 & & 7.7 & 0.15 & 80 & 960 & 0.17 & 446 & 0.31 \\
\hline $33-4(140-150)$ & 379.90 & & 7.8 & 0.12 & 208 & 1125 & 0.25 & 489 & 0.00 \\
\hline $33-5(139-140)$ & 381.39 & & 7.3 & 0.14 & 107 & 1093 & 0.21 & 447 & 0.30 \\
\hline $34-1(64-65)$ & 384.14 & & 8.8 & 0.13 & 69 & 869 & 0.15 & 418 & 0.43 \\
\hline $34-3(84-85)$ & 387.34 & & 6.6 & 0.57 & 107 & 346 & 0.77 & 420 & 0.21 \\
\hline $34-5(83-84)$ & 390.33 & Unit IVB & 5.2 & 0.21 & 86 & 1029 & 0.27 & 424 & 0.35 \\
\hline $34-7(15-16)$ & 392.65 & & 5.6 & 0.33 & 100 & 621 & 0.46 & 424 & 0.28 \\
\hline $35-2(81-83)$ & 395.31 & & 7.9 & 0.10 & 30 & 1360 & 0.05 & 416 & 0.50 \\
\hline $36-2(58-59)$ & 399.58 & & 8.6 & 0.24 & 29 & 629 & 0.13 & 370 & 0.50 \\
\hline $36-3(7-8)$ & 400.57 & & 8.6 & 0.19 & 47 & 758 & 0.14 & 427 & 0.36 \\
\hline $37-2(66-67)$ & 404.66 & & 7.8 & 0.12 & 25 & 1167 & 0.06 & 320 & 0.50 \\
\hline $37-2(120-130)$ & 405.20 & & 8.2 & 0.11 & 282 & 1210 & 0.34 & 503 & 0.09 \\
\hline $37-4(66-67)$ & 407.66 & & 8.1 & 0.28 & 79 & 646 & 0.29 & 413 & 0.25 \\
\hline $38-1(56-57)$ & 412.56 & & 8.2 & 0.11 & 36 & 1355 & 0.09 & 379 & 0.62 \\
\hline $38-3(122-123)$ & 416.22 & & 8.6 & 0.12 & 58 & 958 & 0.15 & 358 & 0.57 \\
\hline $39-1(20-21)$ & 421.70 & & 3.6 & 0.62 & 71 & 300 & 0.59 & 410 & 0.26 \\
\hline $40-1(20-21)$ & 431.20 & & 2.4 & 0.53 & 75 & 336 & 0.58 & 411 & 0.31 \\
\hline $40-1(140-150)$ & 432.40 & & 3.4 & 0.60 & 145 & 405 & 0.95 & 420 & 0.09 \\
\hline $41-1(20-21)$ & 440.70 & & 1.9 & 0.47 & 68 & 379 & 0.47 & 404 & 0.33 \\
\hline $42-2(140-141)$ & 452.90 & & 3.7 & 0.50 & 76 & 358 & 0.50 & 415 & 0.24 \\
\hline $43-1(21-22)$ & 459.71 & & 3.4 & 0.92 & 96 & 220 & 1.04 & 419 & 0.15 \\
\hline $43-2(120-130)$ & 462.20 & & 2.6 & 0.47 & 47 & 494 & 0.31 & 412 & 0.29 \\
\hline $44-1(77-78)$ & 469.77 & & 3.0 & 0.43 & 74 & 398 & 0.47 & 408 & 0.33 \\
\hline $44-3(35-36)$ & 472.35 & & 4.4 & 0.60 & 42 & 327 & 0.33 & 413 & 0.25 \\
\hline $44-5(26-27)$ & 475.26 & & 5.3 & 0.40 & 70 & 443 & 0.40 & 409 & 0.30 \\
\hline $45-1(16-17)$ & 478.66 & & 3.3 & 0.41 & 71 & 483 & 0.40 & 410 & 0.27 \\
\hline $45-3(16-17)$ & 481.86 & & 5.1 & 0.44 & 73 & 414 & 0.47 & 408 & 0.33 \\
\hline $46-1(62-63)$ & 488.62 & & 3.4 & 0.81 & 62 & 274 & 0.62 & 421 & 0.19 \\
\hline $46-2(120-125)$ & 490.70 & & 3.2 & 0.66 & 95 & 294 & 0.70 & 420 & 0.10 \\
\hline $46-3(62-63)$ & 491.62 & & 3.7 & 0.50 & 60 & 414 & 0.40 & 413 & 0.25 \\
\hline $47-1(52-53)$ & 498.02 & & 3.4 & 0.49 & 63 & 518 & 0.45 & 412 & 0.32 \\
\hline $47-3(52-53)$ & 501.02 & & 3.7 & 0.51 & 75 & 469 & 0.50 & 414 & 0.24 \\
\hline $48-1$ (52-53) & 507.52 & & 3.4 & 0.83 & 93 & 284 & 0.94 & 421 & 0.18 \\
\hline $49-1(52-53)$ & 517.02 & & 2.6 & 0.60 & 80 & 462 & 0.62 & 417 & 0.23 \\
\hline $49-2(120-130)$ & 519.20 & & 3.2 & 0.68 & 71 & 387 & 0.60 & 417 & 0.20 \\
\hline 50-1 (82-83) & 526.82 & & 2.5 & 0.67 & 81 & 337 & 0.69 & 415 & 0.22 \\
\hline $50-3(82-83)$ & 529.82 & & 3.1 & 0.66 & 88 & 368 & 0.73 & 416 & 0.21 \\
\hline $51-1(52-53)$ & 536.02 & & 3.1 & 0.74 & 84 & 368 & 0.76 & 418 & 0.18 \\
\hline $51-3(52-53)$ & 539.02 & & 4.3 & 0.69 & 80 & 325 & 0.65 & 418 & 0.16 \\
\hline $52-1(52-53)$ & 545.52 & & 3.7 & 0.70 & 93 & 430 & 0.79 & 420 & 0.18 \\
\hline $52-2(145-150)$ & 547.95 & & 4.2 & 0.66 & 91 & 298 & 0.71 & 414 & 0.16 \\
\hline $52-3(52-53)$ & 548.52 & & 4.0 & 0.70 & 83 & 389 & 0.71 & 416 & 0.19 \\
\hline $53-1(52-53)$ & 555.02 & & 4.3 & 0.79 & 95 & 308 & 0.86 & 420 & 0.13 \\
\hline $54-2(70-72)$ & 566.20 & & 3.9 & 0.92 & 104 & 233 & 1.07 & 425 & 0.10 \\
\hline $55-1(23-24)$ & 573.73 & & 1.9 & 0.70 & 111 & 274 & 0.89 & 425 & 0.12 \\
\hline $55-5(120-130)$ & 580.70 & & 3.9 & 0.63 & 86 & 452 & 0.59 & 416 & 0.09 \\
\hline $56-1(55-56)$ & 583.55 & & 3.8 & 0.80 & 120 & 226 & 1.08 & 424 & 0.11 \\
\hline $57-1(52-53)$ & 593.02 & & 3.9 & 1.02 & 134 & 215 & 1.52 & 426 & 0.10 \\
\hline $57-3(52-53)$ & 596.02 & & 4.4 & 0.85 & 112 & 252 & 1.07 & 421 & 0.11 \\
\hline $57-5(52-53)$ & 599.02 & & 4.1 & 0.74 & 103 & 281 & 0.88 & 420 & 0.14 \\
\hline $58-1(52-53)$ & 602.52 & Unit $\mathrm{V}$ & 4.2 & 0.74 & 108 & 396 & 0.95 & 421 & 0.16 \\
\hline $58-3(52-53)$ & 605.52 & & 2.5 & 0.87 & 99 & 277 & 1.01 & 424 & 0.15 \\
\hline $58-4(120-125)$ & 607.70 & & 3.2 & 0.97 & 88 & 252 & 0.98 & 426 & 0.13 \\
\hline
\end{tabular}


Table 4. (Continued).

\begin{tabular}{|c|c|c|c|c|c|c|c|c|c|}
\hline $\begin{array}{l}\text { Core, section } \\
\text { (interval in } \mathrm{cm} \text { ) }\end{array}$ & $\begin{array}{c}\text { Depth } \\
\text { below } \\
\text { seafloor } \\
\text { (m) }\end{array}$ & $\begin{array}{c}\text { Geological } \\
\text { formation } \\
\text { or } \\
\text { Unit }\end{array}$ & $\begin{array}{l}\text { Mineral } \\
\text { carbon } \\
\text { (wt. \%) }\end{array}$ & $\begin{array}{l}\text { Organic } \\
\text { carbon } \\
\text { (wt.\%) }\end{array}$ & $\begin{array}{c}\text { Hydrogen } \\
\text { index } \\
\text { (mg hydro- } \\
\text { carbons } / g \\
\text { OC) }\end{array}$ & $\begin{array}{c}\text { Oxygen } \\
\text { index } \\
(\mathrm{mg} \mathrm{CO} 2 / 8 \\
\left.\mathrm{OC}^{2}\right)\end{array}$ & $\begin{array}{c}\text { Petroleum } \\
\text { potential } \\
\text { (mg hydro- } \\
\text { carbons } / 8 \\
\text { rock) }\end{array}$ & $\begin{array}{c}\text { Pyrolysis } \\
\text { tempera- } \\
\text { ture } \\
\left({ }^{\circ} \mathrm{C}\right)\end{array}$ & $\begin{array}{l}\text { Production } \\
\text { index } \\
\text { (PI) }\end{array}$ \\
\hline \multicolumn{10}{|l|}{ Hole 547A (Cont.) } \\
\hline $58-5(52-53)$ & 606.52 & & 4.9 & 0.96 & 142 & 232 & 1.55 & 426 & 0.12 \\
\hline $59-1(52-53)$ & 612.02 & & 3.8 & 0.66 & 103 & 298 & 0.78 & 422 & 0.13 \\
\hline $59-3(52-53)$ & 615.02 & & 4.4 & 0.67 & 100 & 349 & 0.78 & 421 & 0.14 \\
\hline $59-5(52-53)$ & 618.02 & & 4.9 & 0.94 & 119 & 225 & 1.23 & 427 & 0.09 \\
\hline $60-1(52-53)$ & 622.02 & & 2.5 & 0.80 & 83 & 251 & 0.78 & 419 & 0.15 \\
\hline $60-3(52-53)$ & 625.02 & & 2.6 & 0.73 & 88 & 255 & 0.76 & 419 & 0.16 \\
\hline $60-5(52-53)$ & 628.02 & & 4.1 & 0.85 & 75 & 234 & 0.77 & 421 & 0.17 \\
\hline $61-1(52-53)$ & 631.02 & & 4.3 & 0.60 & 88 & 390 & 0.64 & 419 & 0.17 \\
\hline $61-3(52-53)$ & 634.02 & & 3.9 & 0.69 & 80 & 291 & 0.64 & 417 & 0.14 \\
\hline $61-3(140-150)$ & 634.90 & & 3.8 & 0.62 & 56 & 440 & 0.45 & 414 & 0.22 \\
\hline $62-1(52-53)$ & 640.52 & & 3.8 & 0.75 & 87 & 336 & 0.75 & 420 & 0.14 \\
\hline $62-3(52-53)$ & 643.52 & & 3.4 & 0.55 & 78 & 347 & 0.51 & 418 & 0.16 \\
\hline $63-1(52-53)$ & 650.02 & & 4.9 & 0.96 & 106 & 219 & 1.11 & 428 & 0.08 \\
\hline $63-3(52-53)$ & 653.02 & & 5.3 & 0.90 & 129 & 233 & 1.28 & 427 & 0.09 \\
\hline $64-1(52-53)$ & 659.52 & & 4.3 & 0.94 & 117 & 206 & 1.21 & 427 & 0.09 \\
\hline $64-2(120-125)$ & 661.70 & & 4.5 & 0.74 & 103 & 284 & 0.85 & 423 & 0.11 \\
\hline $64-3(52-53)$ & 662.52 & & 4.6 & 0.88 & 89 & 216 & 0.88 & 423 & 0.11 \\
\hline $66-1(34-35)$ & 678.34 & & 4.1 & 0.81 & 41 & 278 & 0.40 & 413 & 0.17 \\
\hline $67-2(34-35)$ & 689.34 & & 6.9 & 0.68 & 119 & 207 & 0.88 & 427 & 0.08 \\
\hline $67-2(120-125)$ & 690.20 & & 5.5 & 1.17 & 198 & 197 & 2.40 & 431 & 0.03 \\
\hline $68-1(68-70)$ & 697.68 & & 5.5 & 0.71 & 77 & 286 & 0.62 & 420 & 0.11 \\
\hline $69-1(52-55)$ & 707.02 & & 7.3 & 0.69 & 129 & 241 & 0.99 & 429 & 0.10 \\
\hline $69-3(52-53)$ & 710.02 & & 5.8 & 1.39 & 171 & 157 & 2.36 & 433 & 0.06 \\
\hline $70-1(52-53)$ & 716.52 & & 8.1 & 0.68 & 150 & 245 & f.11 & 429 & 0.08 \\
\hline $70-2(106-116)$ & 718.56 & & 7.6 & 0.73 & 145 & 295 & 1.10 & 428 & 0.04 \\
\hline $70-3(52-53)$ & 719.52 & & 5.6 & 1.11 & 195 & 229 & 2.32 & 432 & 0.06 \\
\hline $71-1(52-53)$ & 721.02 & & 7.1 & 0.72 & 190 & 242 & 1.51 & 431 & 0.09 \\
\hline $72-1(52-53)$ & 726.02 & & 7.4 & 0.58 & 138 & 246 & 0.90 & 424 & 0.11 \\
\hline $72-3(52-53)$ & 729.02 & & 8.6 & 0.45 & 127 & 284 & 0.64 & 426 & 0.11 \\
\hline $73-1(52-53)$ & 735.52 & & 5.2 & 0.88 & 130 & 259 & 1.25 & 424 & 0.09 \\
\hline $73-3(52-53)$ & 738.52 & & 4.6 & 1.10 & 188 & 228 & 2.21 & 430 & 0.06 \\
\hline $73-3(120-125)$ & 739.20 & & 4.2 & 1.28 & 171 & 225 & 2.34 & 430 & 0.06 \\
\hline \multicolumn{10}{|l|}{ Hole 547B } \\
\hline $2-1(52-53)$ & 734.52 & \multirow{9}{*}{ Unit $\mathrm{V}$} & 6.3 & 1.12 & 147 & 178 & 1.77 & 428 & 0.07 \\
\hline $2-3(52-53)$ & 737.52 & & 3.4 & 1.34 & 157 & 153 & 2.23 & 429 & 0.06 \\
\hline $2-4(120-130)$ & 739.70 & & 1.7 & 1.13 & 128 & 262 & 1.64 & 426 & 0.12 \\
\hline $2-5(52-53)$ & 740.52 & & 3.4 & 1.34 & 148 & 187 & 2.09 & 428 & 0.05 \\
\hline $4-3(70-71)$ & 756.70 & & 5.3 & 1.45 & 224 & 135 & 3.39 & 431 & 0.04 \\
\hline $5-1(52-53)$ & 763.02 & & 4.3 & 1.13 & 180 & 209 & 2.16 & 431 & 0.06 \\
\hline $5-3(52-53)$ & 766.02 & & 4.1 & 1.10 & 185 & 252 & 2.18 & 430 & 0.07 \\
\hline $5-5(52-53)$ & 769.02 & & 4.3 & 1.49 & 213 & 146 & 3.41 & 427 & 0.07 \\
\hline $5-6(113-123)$ & 769.63 & & 4.1 & 1.16 & 181 & 234 & 2.27 & 431 & 0.07 \\
\hline $22-1(15-16)$ & 915.15 & Unit VIB & 1.9 & 0.73 & 60 & 185 & 0.49 & 475 & 0.10 \\
\hline $25-3(100-101)$ & 936.43 & \multirow{16}{*}{ Unit VII } & 2.9 & 0.40 & 128 & 48 & 0.57 & 461 & 0.11 \\
\hline $25-3(93-94)$ & 936.50 & & 3.9 & 0.18 & 255 & 205 & 0.52 & 473 & 0.12 \\
\hline $25-4(0-5)$ & 937.00 & & 2.5 & 0.41 & 24 & 95 & 0.13 & 436 & 0.23 \\
\hline $26-2(102-103)$ & 944.02 & & 2.6 & 0.18 & 111 & 311 & 0.25 & 467 & 0.21 \\
\hline $26-4(62-64)$ & 946.62 & & 4.3 & 0.36 & 136 & 122 & 0.55 & 444 & 0.11 \\
\hline $27-2(64-65)$ & 952.64 & & 3.6 & 0.40 & 45 & 470 & 0.23 & 478 & 0.23 \\
\hline $27-2(112-113)$ & 953.12 & & 1.7 & 0.15 & 187 & 393 & 0.34 & 454 & 0.18 \\
\hline $27-3(112-113)$ & 954.62 & & 3.6 & 0.23 & 74 & 248 & 0.21 & 479 & 0.20 \\
\hline $28-3(83-84)$ & 963.33 & & 3.2 & 0.14 & 136 & 379 & 0.23 & 478 & 0.18 \\
\hline $29-1(36-37)$ & 968.86 & & 6.6 & 0.21 & 105 & 1114 & 0.32 & 397 & 0.31 \\
\hline $29-1(112-113)$ & 969.62 & & 4.0 & 0.31 & 58 & 177 & 0.21 & 478 & 0.15 \\
\hline $30-3(82-83)$ & 981.32 & & 3.3 & 0.29 & 59 & 176 & 0.20 & 467 & 0.15 \\
\hline $30-4(50-55)$ & 982.60 & & 2.6 & 0.19 & 168 & 253 & 0.32 & 476 & 0.00 \\
\hline $31-3(92-93)$ & 990.42 & & 3.2 & 0.15 & 67 & 460 & 0.14 & 457 & 0.29 \\
\hline $32, \mathrm{CC}(23-24)$ & 1000.00 & & 2.3 & 0.11 & 64 & 482 & 0.10 & 410 & 0.30 \\
\hline $34-1(145-150)$ & 1010.95 & & 2.4 & 0.07 & 414 & 886 & 0.29 & 444 & 0.00 \\
\hline
\end{tabular}


ORGANIC GEOCHEMISTRY OF CENOZOIC AND MESOZOIC SEDIMENTS

Table 5. Hole 370 .

\begin{tabular}{|c|c|c|c|c|c|c|c|c|c|}
\hline $\begin{array}{c}\text { Core, section } \\
\text { (interval in cm) }\end{array}$ & $\begin{array}{l}\text { Depth } \\
\text { below } \\
\text { seafloor } \\
\text { (m) }\end{array}$ & $\begin{array}{c}\text { Geological } \\
\text { formation } \\
\text { or } \\
\text { Unit }\end{array}$ & $\begin{array}{l}\text { Mineral } \\
\text { carbon } \\
\text { (wt.\%) }\end{array}$ & $\begin{array}{l}\text { Organic } \\
\text { carbon } \\
\text { (wt.\%) }\end{array}$ & $\begin{array}{l}\text { Hydrogen } \\
\text { index } \\
\text { (mg hydro- } \\
\text { carbons } / g \\
\text { OC) }\end{array}$ & $\begin{array}{c}\text { Oxygen } \\
\text { index } \\
(\mathrm{mg} \mathrm{CO} 2 / \mathrm{g} \\
\mathrm{OC}^{2}\end{array}$ & $\begin{array}{c}\text { Petroleum } \\
\text { potential } \\
\text { (mg hydro- } \\
\text { carbons } / \mathrm{g} \\
\text { rock) }\end{array}$ & $\begin{array}{c}\text { Pyrolysis } \\
\text { tempera- } \\
\text { ture } \\
\left({ }^{\circ} \mathrm{C}\right)\end{array}$ & $\begin{array}{l}\text { Production } \\
\text { index } \\
\text { (PI) }\end{array}$ \\
\hline $19-1(68-73)$ & 654.70 & Unit IV & 5.3 & 0.48 & 123 & 450 & 0.61 & 426 & \\
\hline $20-1(65-70)$ & $673.70^{-}$ & & 2.0 & 0.62 & 69 & 347 & 0.48 & 422 & 0.05 \\
\hline $20-2(82-85)$ & 675.30 & & 3.7 & 0.58 & 89 & 297 & 0.53 & 423 & \\
\hline $20-2(94-96)$ & 675.44 & & 0.4 & 0.82 & 49 & 196 & 0.44 & 426 & 0.04 \\
\hline $20-3(43-45)$ & 676.43 & & 2.0 & 0.97 & 66 & 281 & 0.69 & 414 & 0.05 \\
\hline $20-3(110-112)$ & 677.10 & & 2.8 & 0.66 & 63 & 408 & 0.46 & 418 & 0.04 \\
\hline $21-2(110-112)$ & 685.10 & & 2.2 & 0.62 & 65 & 395 & 0.45 & 423 & 0.04 \\
\hline $21-2(119-121)$ & 685.19 & & 0.9 & 0.77 & 48 & 279 & 0.40 & 426 & 0.03 \\
\hline $22-2(26-28)$ & 693.76 & & 0.8 & 0.72 & 46 & 419 & 0.37 & 426 & 0.04 \\
\hline $22-3(39-41)$ & 695.39 & & 1.6 & 0.65 & 83 & 335 & 0.58 & 417 & 0.04 \\
\hline $22-4(76-78)$ & 697.26 & & 2.5 & 0.40 & 46 & 593 & 0.19 & 426 & 0.01 \\
\hline $23-2(52-56)$ & 703.50 & & 2.3 & 0.43 & 61 & 302 & 0.27 & 424 & \\
\hline $23-2(123-125)$ & 704.23 & & 0.7 & 0.66 & 45 & 397 & 0.33 & 411 & 0.04 \\
\hline $23-3(19-21)$ & 704.69 & & 1.0 & 0.58 & 48 & 326 & 0.28 & 426 & 0.00 \\
\hline $23-4(84-86)$ & 706.84 & & 1.9 & 0.37 & 59 & 419 & 0.24 & 438 & 0.03 \\
\hline $23-4(109-111)$ & 707.09 & & 2.8 & 0.31 & 31 & 461 & 0.10 & 414 & 0.01 \\
\hline $23-4(139-141)$ & 707.39 & & 5.6 & 0.21 & 1 & 1019 & 0.02 & & 0.02 \\
\hline $24-2(47-50)$ & 713.00 & & 2.7 & 0.60 & 67 & 245 & 0.42 & 420 & \\
\hline $24-3(27-28)$ & 714.27 & & 7.1 & 0.28 & 44 & 489 & 0.15 & 404 & 0.03 \\
\hline $24-3(28-30)$ & 714.28 & & 3.9 & 0.28 & 1 & 689 & 0.02 & 419 & 0.02 \\
\hline $24-3(59-61)$ & 714.59 & & 0.8 & 0.96 & 55 & 175 & 0.56 & 425 & 0.03 \\
\hline $24-3$ (113-115) & 715.13 & & 2.2 & 0.33 & 46 & 403 & 0.20 & & 0.05 \\
\hline $24-5(11-13)$ & 717.11 & & 1.8 & 1.04 & 77 & 258 & 0.84 & 425 & 0.04 \\
\hline $24-5(62-64)$ & 717.62 & & 1.8 & 0.31 & 34 & 623 & 0.15 & 440 & 0.05 \\
\hline $25-1(139-141)$ & 722.89 & & 1.5 & 0.52 & 45 & 310 & 0.38 & 401 & 0.15 \\
\hline $25-2(73-75)$ & 723.73 & & 0.6 & 0.84 & 52 & 155 & 0.47 & 430 & 0.03 \\
\hline $25-2(114-116)$ & 724.14 & & 1.2 & 0.64 & 74 & 278 & 0.54 & 425 & 0.06 \\
\hline $25-2(135-137)$ & 724.35 & & 1.3 & 0.26 & 57 & 269 & 0.19 & 421 & 0.05 \\
\hline $25-2(145-147)$ & 724.45 & & 1.7 & 0.32 & 41 & 606 & 0.20 & 432 & 0.07 \\
\hline $26-2(30-32)$ & 731.80 & & 1.7 & 0.48 & $5 i$ & 373 & 0.31 & 417 & 0.06 \\
\hline $26-2(54-56)$ & 732.04 & & 1.2 & 1.28 & 95 & 198 & 1.28 & 433 & 0.06 \\
\hline $26-3(22-25)$ & 733.20 & & 2.4 & 0.52 & 71 & 194 & 0.38 & 422 & \\
\hline $26-3(93-95)$ & 733.93 & & 2.0 & 0.63 & 54 & 192 & 0.35 & 428 & 0.02 \\
\hline $26-4(9-11)$ & 734.59 & & 3.0 & 0.41 & 62 & 490 & 0.30 & 417 & 0.05 \\
\hline $26-4(112-114)$ & 735.62 & & 1.4 & 1.10 & 115 & 232 & 1.43 & 421 & 0.17 \\
\hline $27-1(124-126)$ & 750.24 & & 1.7 & 1.58 & 207 & 111 & 3.40 & 423 & 0.13 \\
\hline $27-1(127-129)$ & 750.27 & & 1.5 & 0.24 & 42 & 175 & 0.21 & & 0.11 \\
\hline $27-3(6-8)$ & 752.06 & & 1.5 & 0.77 & 143 & 87 & 1.17 & 422 & 0.07 \\
\hline $27-3(10-12)$ & 752.10 & & 1.6 & 2.05 & 246 & 70 & 5.17 & 432 & 0.13 \\
\hline $27-3(23-25)$ & 752.23 & & 2.4 & 2.75 & 324 & 101 & 9.04 & 419 & 0.13 \\
\hline $27-3(101-103)$ & 753.01 & & 0.4 & 3.44 & 288 & 34 & 10.03 & 409 & 0.11 \\
\hline $28-2(19-23)$ & 769.70 & & 0.6 & 0.27 & 223 & 122 & 0.62 & 432 & \\
\hline $28=2(70-72)$ & 770.20 & & 0.7 & 1.09 & 186 & 68 & 2.11 & 422 & 0.08 \\
\hline $28-2(77-79)$ & 770.27 & Unit $\mathrm{V}$ & 0.4 & 0.49 & 115 & 80 & 0.63 & 417 & 0.07 \\
\hline $28-3(103-105)$ & 772.03 & & 0.6 & 0.68 & 51 & 179 & 0.38 & 428 & 0.03 \\
\hline $28-4(116-118)$ & 773.66 & & 0.4 & 0.48 & 101 & 100 & 0.56 & 413 & 0.07 \\
\hline $28-4(142-144)$ & 773.92 & & 0.6 & 1.20 & 178 & 69 & 2.21 & 422 & 0.07 \\
\hline $29-1(104-106)$ & 788.04 & & 0.0 & 0.74 & 99 & 26 & 0.77 & 438 & 0.04 \\
\hline $30-1(139-141)$ & 807.39 & & 0.5 & 0.24 & 34 & 142 & 0.23 & & 0.14 \\
\hline $30-2(31-36)$ & 807.81 & & 0.8 & 0.17 & 224 & 129 & 0.36 & 441 & 0.06 \\
\hline $30-2(61-63)$ & 808.11 & & 0.0 & 3.99 & 349 & 24 & 14.06 & 426 & 0.15 \\
\hline $30-2(64-66)$ & 808.14 & & 0.8 & 3.08 & 317 & 59 & 9.86 & 428 & 0.01 \\
\hline $30-2(66-68)$ & 808.16 & & 0.7 & 2.07 & 205 & 50 & 4.32 & 426 & 0.02 \\
\hline $30-2(68-70)$ & 808.18 & & 1.4 & 1.80 & 278 & 98 & 5.08 & 434 & 0.01 \\
\hline $30-3(102-104)$ & 810.02 & & 0.1 & 2.34 & 194 & 56 & 4.62 & 427 & 0.02 \\
\hline $30-3(115-117)$ & 810.15 & & 0.7 & 1.37 & 127 & 62 & 1.85 & 423 & 0.06 \\
\hline $30-3(126-128)$ & 810.26 & & 0.8 & 0.28 & 42 & 150 & 0.16 & & 0.24 \\
\hline $31-1(46-50)$ & 825.50 & & 0.7 & 0.18 & 197 & 167 & 0.37 & & 0.04 \\
\hline $31-1(109-111)$ & 826.09 & & 1.5 & 1.22 & 185 & i1s & 2.34 & 424 & 0.03 \\
\hline $31-1(114-116)$ & 826.14 & & 0.6 & 0.52 & 86 & 102 & 0.51 & 414 & 0.13 \\
\hline $31-2(24-26)$ & 826.74 & & 2.8 & 1.38 & 320 & 130 & 4.49 & 420 & 0.02 \\
\hline $31-3(26-28)$ & 828.26 & & 0.6 & 2.03 & 230 & 53 & 4.74 & 430 & 0.02 \\
\hline $31-3(47-49)$ & 828.47 & & 0.8 & 0.19 & 22 & 132 & 0.13 & & 0.67 \\
\hline $31-3(126-168)$ & 829.26 & & 0.0 & 4.52 & 362 & 19 & 16.43 & 426 & 0.01 \\
\hline $31-4(146-148)$ & 830.96 & & 1.6 & 5.29 & 457 & 63 & 24.19 & 418 & 0.00 \\
\hline $32-3(38-40)$ & 837.88 & & 2.8 & 6.16 & 503 & 67 & 30.99 & 416 & 0.00 \\
\hline $32-3(82-86)$ & 838.30 & & 2.2 & 4.10 & 431 & 56 & 17.79 & 425 & 0.01 \\
\hline $32-3(79-81)$ & 838.76 & & 0.0 & 4.30 & 459 & 35 & 19.97 & 428 & 0.01 \\
\hline $32-4(19-21)$ & 839.19 & & 0.6 & 0.24 & 120 & 221 & 0.36 & 420 & 0.21 \\
\hline $32-4(70-72)$ & 839.70 & & 0.6 & 1.68 & 134 & 54 & 2.29 & 427 & 0.02 \\
\hline $32-4(99-100)$ & 839.99 & & 2.4 & 1.77 & 198 & 130 & 3.57 & 427 & 0.02 \\
\hline $32-4(132-134)$ & 840.3 & & 3.4 & 0.87 & 180 & 148 & 1.61 & 424 & 0.03 \\
\hline $33, \mathrm{CC}$ & 853.50 & & 1.3 & 0.87 & 59 & 224 & 0.55 & 430 & 0.05 \\
\hline 33. CC & 854.00 & & 3.4 & 0.92 & 137 & 167 & 1.28 & 427 & 0.02 \\
\hline $34-2(63-65)$ & 874.63 & & 5.2 & 0.56 & 90 & 161 & 0.54 & 422 & 0.07 \\
\hline $34-2(81-83)$ & 874.81 & & 3.7 & 0.99 & 149 & 233 & 1.57 & 416 & 0.07 \\
\hline $34-2$ (116-118) & 875.16 & & 3.8 & 0.78 & 107 & 153 & 0.88 & 427 & 0.05 \\
\hline $34-3(102-104)$ & 876.52 & & 1.8 & 1.19 & 124 & 151 & 1.51 & 424 & 0.02 \\
\hline $34-4$ (113-114) & 878.13 & & 9.6 & 1.27 & 11 & 49 & 0.19 & 425 & 0.23 \\
\hline $34-5(99-100)$ & 879.49 & & 9.2 & 2.34 & 5 & 23 & 0.18 & 412 & 0.29 \\
\hline $35-5(22-24)$ & 885.22 & & 1.6 & 0.42 & 79 & 245 & 0.39 & 437 & 0.15 \\
\hline $35-4(38-40)$ & 886.88 & & 3.6 & 1.08 & 131 & 212 & 1.48 & 433 & 0.05 \\
\hline $35-4(82-84)$ & 887.32 & & 3.4 & 0.26 & 17 & 569 & 0.19 & & 0.77 \\
\hline $35-5(10-12)$ & 888.10 & & 2.8 & 1.65 & 95 & 110 & 1.65 & 428 & 0.05 \\
\hline $35-5(49-42)$ & 888.40 & & 3.0 & 1.61 & 196 & 149 & 3.23 & 422 & 0.02 \\
\hline $35-5(52-54)$ & 888.52 & & 0.4 & 3.12 & 208 & 56 & 6.56 & 426 & 0.01 \\
\hline
\end{tabular}

